\title{
Advances in Struvite Precipitation Technologies for Nutrients Removal and Recovery from Aqueous Waste and Wastewater
}

\author{
Alessio Siciliano ${ }^{1, *(\mathbb{D}}$, Carlo Limonti $^{1}{ }^{1}$, , Giulia Maria Curcio $^{1}\left(\mathbb{C}\right.$ and Raffaele Molinari ${ }^{2}(\mathbb{C}$ \\ 1 Laboratory of Environmental Sanitary Engineering, Department of Environmental Engineering, \\ University of Calabria, 87036 Rende (CS), Italy; carlo.limonti@unical.it (C.L.); \\ gmaria.curcio@unical.it (G.M.C.) \\ 2 Laboratory of Chemical Fundaments of Membrane Technologies, Department of Environmental Engineering, \\ University of Calabria, 87036 Rende (CS), Italy; raffaele.molinari@unical.it \\ * Correspondence: alessio.siciliano@unical.it; Tel.: +39-098-449-6537
}

Received: 14 August 2020; Accepted: 4 September 2020; Published: 12 September 2020

\begin{abstract}
The abatement of nutrient compounds from aqueous waste and wastewater is currently a priority issue. Indeed, the uncontrolled discharge of high levels of nutrients into water bodies causes serious deteriorations of environmental quality. On the other hand, the increasing request of nutrient compounds for agronomic utilizations makes it strictly necessary to identify technologies able to recover the nutrients from wastewater streams so as to avoid the consumption of natural resources. In this regard, the removal and recovery of nitrogen and phosphorus from aqueous waste and wastewater as struvite $\left(\mathrm{MgNH}_{4} \mathrm{PO}_{4} \cdot 6 \mathrm{H}_{2} \mathrm{O}\right)$ represents an attractive approach. Indeed, through the struvite precipitation it is possible to effectively remove the ammonium and phosphate content of many types of wastewater and to produce a solid compound, with only a trace of impurities. This precipitate, due to its chemical characteristics, represents a valuable multi-nutrients slow release fertilizer for vegetables and plants growth. For these reasons, the struvite precipitation technology constantly progresses on several aspects of the process. This manuscript provides a comprehensive review on the recent developments in this technology for the removal and recovery of nutrients from aqueous waste and wastewater. The theoretical background, the parameters, and the operating conditions affecting the process evolution are initially presented. After that, the paper focuses on the reagents exploitable to promote the process performance, with particular regard to unconventional low-cost compounds. In addition, the development of reactors configurations, the main technologies implemented on field scale, as well as the recent works on the use of struvite in agronomic practices are presented.
\end{abstract}

Keywords: ammonium; magnesium; MAP; nutrients recovery; phosphorus; struvite

\section{Introduction}

The definition of proper processes for the management and the treatment of waste and wastewater is a crucial environmental and social topic. The uncontrolled discharge can induce serious deteriorations of soil and water bodies quality. In particular, the release in the environment of aqueous waste with high amounts of nutrients (nitrogen and phosphorus compounds) is of great concern [1-4]. In fact, this practice induces eutrophication phenomena in superficial water bodies and, consequently, the exhaustion of $\mathrm{O}_{2}$ content [5]. As a consequence of eutrophication phenomena, episodes of harmful algal blooms (HAB) could occur. HAB can release harmful toxins which pose a notable risk for human health and environmental ecosystems [6]. Additional drawbacks take place as some nitrogen compounds $\left(\mathrm{NH}_{3}, \mathrm{NO}_{2}{ }^{-}, \mathrm{NO}_{3}{ }^{-}\right)$are harmful to aquatic life or may cause disease if drinking water is 
polluted with these elements [7]. The accumulation of nutrient compounds in aquatic environments is mostly attributable to the use in agricultural activities of chemical fertilizers, animal manures and digestates, as well as to the discharge of urban and industrial wastewater [4,8-15].

Numerous biological and physical-chemical treatments for the abatement of nutrients have been developed. The nitrogen compounds can be removed through typical biological nitrification-denitrification processes $[5,15,16]$. These processes are widely used and effective for $\mathrm{NH}_{4}^{+}$ removal in municipal treatment plants, but they are not very suitable for treating high concentrated wastewaters [17]. Indeed, a high ammonium content has toxic effects on microorganisms, which may cause a significant reduction in the process efficiency [1]. Shortcut nitrification/denitrification and anaerobic ammonium oxidation, showed potential to overcome the drawbacks above mentioned and they could be applied in the treatment of high polluting matrix such as leachates, digestates, etc. Nevertheless, these techniques are still under development and they are quite difficult to control and manage [17].

In the context of chemical-physical treatments, ammonium stripping is one of most widely employed treatments for the abatement of $\mathrm{NH}_{4}{ }^{+}$from highly polluted wastewater. In this process, typically, the $\mathrm{NH}_{3}$, transferred from the wastewater stream to the air flow, is absorbed into acid solutions and recovered as ammoniacal salts. In spite of its benefits, this technology has some limitations, such as the need of $\mathrm{pH}$ adjustment to values close to 11-12 and the requirement of high air flowrates [18].

Breakpoint chlorination can also be applied to oxidize ammonium to nitrogen gas. However, because the process has a number of disadvantages, including the buildup of $\mathrm{HCl}$ and of total dissolved solids, and the formation of unwanted chloro-organic compounds, ammonia oxidation is seldom used today [18].

The abatement of phosphorus from municipal wastewater can be obtained in biological treatment plants which promote the growth of $\mathrm{P}$-accumulating microorganisms. Many different processes have been developed (photoredox $\mathrm{A} / \mathrm{O}, \mathrm{A}^{2} / \mathrm{O}$, Bardenpho, etc.) that assure good efficiencies [18]. A limitation of many of these processes is the occurrence of a decline in phosphorus removal when the nitrogen abatement is contextually applied [18]. In wastewater treatment plants the $\mathrm{P}$ abatement and recovery is also conducted through the precipitation of phosphates with the addition of coagulants which generally consist of inorganic salts of multivalent metal ions, such as calcium, aluminum, and iron. These processes are widely applied due to the easy management and simplicity of the required equipment. Moreover, they can be exploited also in the treatment of concentrated aqueous waste and wastewater. On the other hand, the use of coagulants generates high amounts of voluminous sludge which incorporates the organic solids resulting in a heterogeneous matrix which is difficult to manage.

Additional techniques, such as adsorption, ion exchange, reverse osmosis, etc., could be potentially applicable to remove nutrient compounds [3,18]. However, these techniques are not selective and generate concentrated streams, of which disposal is very expensive.

Among the many alternatives, a solution based on nutrients recovery and reuse is very advantageous as it promotes the development of sustainable technologies. In effect, the definition of a virtuous cycle of nutrients to reduce the use of natural resources and, at the same time, avoid pollution phenomena is, currently, a key challenge. The recovery of nutrients is a strict necessity especially in the case of phosphorus. In fact, nowadays phosphorus is mainly obtained by extractive activity $[19,20]$. The extractive peak of phosphatic rocks will be reached in the next decades and the phosphorus reserves can decrease drastically in the next century [20]. When phosphate rocks drop, extraction and marketing prices will also rise, and industry will be forced to seek alternative sources due to higher demand of phosphorus in the agricultural world. Therefore, the attention of the international scientific community is directed towards the search for sustainable sources of phosphorus and more generally of nutrients. In this regard, the European Commission recently revised the EU Fertilizer Regulation ((EC) 2003/2003) and published the new EU Regulation ((EU) 2019/1009), which includes the fertilizing compounds based on secondary raw materials [10]. 
Many raw materials recoverable from the treatment of aqueous waste and wastewater could potentially become component materials in the new Regulation ((EU) 2019/1009) [10]. In this regard, the recovery of ammonium and phosphates from wastewater as struvite has gained great interest in recent years. Struvite is a white orthorhombic crystalline compound, which is composed of $\mathrm{Mg}^{2+}$, $\mathrm{NH}_{4}{ }^{+}$, and $\mathrm{PO}_{4}{ }^{3-}\left(\mathrm{MgNH}_{4} \mathrm{PO}_{4} \cdot 6 \mathrm{H}_{2} \mathrm{O}\right)$ in equal molar amounts [21,22]. Struvite precipitation takes place when the combination of ammonium, magnesium, and phosphates concentrations overcomes the solubility product under an alkaline environment [23]. In general, struvite precipitation can be aimed to remove and recover the amount of $\mathrm{NH}_{4}{ }^{+}$or $\mathrm{PO}_{4}{ }^{3-}$ from wastewater $[8,24-26]$. The recovery of the phosphates content alone is much more sustainable because lower amounts of reagents are necessary. In fact, at most, the chemicals for magnesium supplying and $\mathrm{pH}$ setting are required. In the case of nitrogen removal, often, due to the limited contents of $\mathrm{Mg}^{2+}$ and $\mathrm{PO}_{4}{ }^{3-}$ with respect to the $\mathrm{NH}_{4}{ }^{+}$concentration, higher dosages of the reagents are needed for the treatment of high concentrated wastewater [1].

Anyway, struvite is widely recovered for nutrients recycling from wastewater because it can be produced a relatively pure precipitate with a great amount of both phosphorus and nitrogen, with only trace amounts of impurities [10]. Indeed, unlike other precipitation processes that exploit coagulant agents, the struvite is formed as a mineral salt that incorporates only low quantities of solids and that can be easily recovered by sedimentation $[27,28]$. Therefore, the formation of voluminous flocculant sludge, containing great quantities of unwanted compounds is avoided. Furthermore, because of its chemical composition, struvite has a demonstrated value as a fertilizer (pure struvite is included in the Regulation EC No 1907/2006 (REACH) as a commercial fertilizer) [29-35]. For these reasons, at present, struvite is the most common recovered compound in pilot and operational facilities in Europe [10]. It was estimated that approximately 15,000 tons are produced in Europe annually [10]. The existing facilities mainly treat urban wastewater to produce struvite, but industrial wastewater, manure, and livestock slurries are also exploited as input aqueous waste [10]. Furthermore, significant struvite quantities are produced outside Europe (USA, Japan, China) [10].

Despite several applications in industrial facilities, the struvite precipitation process is under continuous development. Indeed, a lot of research has been recently carried out to solve some crucial aspects and to improve the process globally.

The aim of this manuscript is to provide a review on the recent progresses on the application of the struvite precipitation processes for the nutrients recovery and recycling from aqueous waste and wastewater. Initially, the basic principles, the parameters, and the operating conditions that affect the process are examined. Afterwards, attention is paid to the reagents that can be used to promote the process, with particular regard to the unconventional ones that can reduce the management costs. The development of reactors for precipitation and recovery, the main technologies implemented at industrial scale, recent studies on the application of recovered struvite as slow release fertilizer, and some economic considerations are also exposed.

\section{Chemical Bases on the Struvite Precipitation Process}

\subsection{Generality on the Struvite Precipitation}

Struvite type crystals consist of orthophosphate $\left(\mathrm{PO}_{4}{ }^{3-}\right)$, magnesium $\left(\mathrm{Mg}^{2+}\right)$, and mono or bi-valent ions such as ammonia $\left(\mathrm{NH}_{4}^{+}\right)$, potassium $\left(\mathrm{K}^{+}\right)$, sodium $\left(\mathrm{Na}^{+}\right)$, copper $\left(\mathrm{Cu}^{2+}\right)$, nickel $\left(\mathrm{Ni}^{2+}\right)$, lead $\left(\mathrm{Pb}^{2+}\right)$, manganese $\left(\mathrm{Mn}^{2+}\right)[9,36]$. Magnesium ammonium phosphate $\left(\mathrm{MgNH}_{4} \mathrm{PO}_{4} \cdot 6 \mathrm{H}_{2} \mathrm{O}\right)$ (acronym MAP), is the most common and stable form which is characterized by a crystalline white orthorhombic prismatic structure (Figure 1). The struvite can be identified through X-ray diffraction (XRD) analysis by comparing the diffractogram of the solid under examination with that of pure compound (Figure 2). The formation occurs when the concentrations of constituents exceed the solubility product. Precipitation takes place according to the following equation [12]:

$$
\mathrm{Mg}^{2+}+\mathrm{NH}_{4}^{+}+\mathrm{H}_{\mathrm{n}} \mathrm{PO}_{4}^{3-\mathrm{n}}+6 \mathrm{H}_{2} \mathrm{O} \rightarrow \mathrm{MgNH}_{4} \mathrm{PO}_{4} \cdot 6 \mathrm{H}_{2} \mathrm{O}+\mathrm{nH}^{+} \text {where } \mathrm{n}=0,1 \text {, or } 2
$$




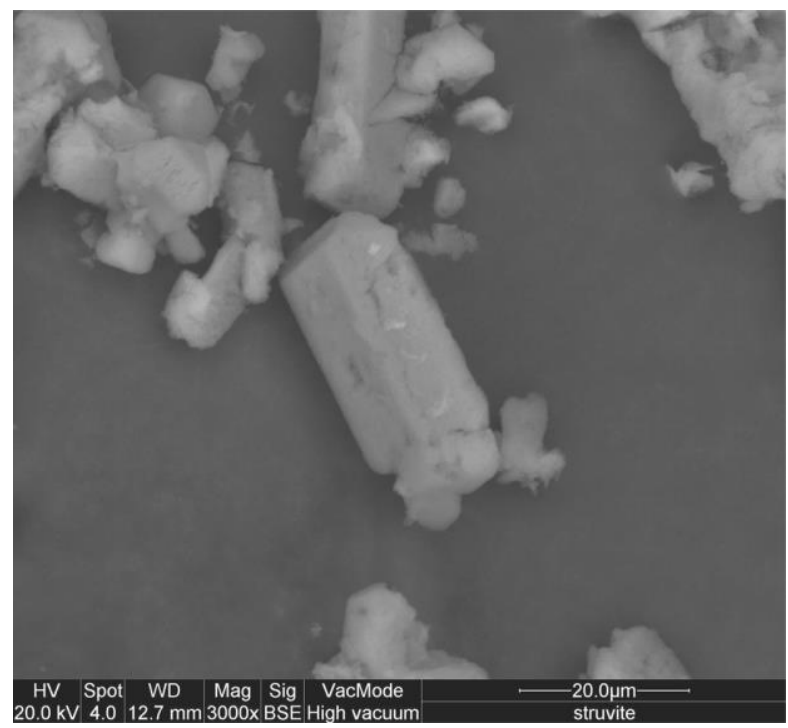

Figure 1. Struvite crystals obtained from the treatment of landfill leachate [41].

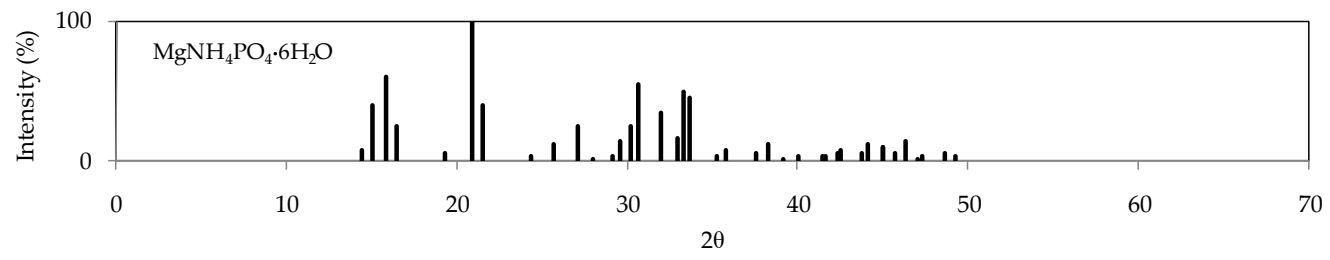

Figure 2. Diffractogram of pure struvite.

Anyhow, this reaction is a simplification of the chemistry of struvite formation. In effect, the process involves different chemical-physical parameters and it can be divided into two main steps: nucleation and growth. In particular, nucleation takes place when the ions combine, generating crystals in their embryonic form [37]. The nucleation process can be homogeneous when it occurs spontaneously, or heterogeneous if it occurs in the presence of foreign particles or impurities, and it is controlled by diffusive mechanisms and by the degree of saturation of the elements in the solution [12]. Struvite crystals growth, instead, is a process controlled by mass transfer mechanisms from the solute to the crystals' surface and by surface integration mechanisms, through which the material is incorporated into the crystals [38]. These mechanisms depend on several physical-chemical parameters such as $\mathrm{pH}$, supersaturation ratio, temperature, and presence of competitive ions [39]. Furthermore, the reaction kinetics of struvite crystals formation is influenced by thermodynamic equilibrium and by liquid-solid transport phenomena [40]. In the following paragraphs the effects of the main parameters on MAP formation are analyzed.

\subsection{Effects of $\mathrm{pH}$ on Struvite Formation}

As mentioned above, struvite formation happens when the concentrations of $\mathrm{Mg}^{2+}, \mathrm{NH}_{4}{ }^{+}$, and $\mathrm{PO}_{4}{ }^{3-}$ exceed the solubility product (Ksp). The availability of the three components is controlled by the $\mathrm{pH}$ and by the overall amounts of magnesium, ammonium, and phosphorus species [42]. The speciation of MAP components is also $\mathrm{pH}$ dependent, therefore, the formation and precipitation of struvite is mainly affected by $\mathrm{pH}$ [32]. Many studies investigated the optimal $\mathrm{pH}$ range for MAP precipitation. Buchanan et al. [43], through a mathematical modeling, found that struvite precipitation in anaerobic lagoons could take place in the $\mathrm{pH}$ range 7-11, with the minimum solubility at $\mathrm{pH} 9$. In agreement with this statement, Siciliano et al. [44] observed that the positive effect of alkaline conditions is not relevant for $\mathrm{pH}$ greater than 9 , for struvite formation in anaerobic digestate. Tünay et al. [45] identified $\mathrm{pH}$ values between 8.5 and 9.3 as the optimal. Hao et al. [46] reported a range $\mathrm{pH} 9-9.5$ 
as the most favorable, with a degree of purity above $90 \%$ of recovered precipitate. Huang et al. [47] stated a rapid raise in the reaction rate of struvite formation in response to $\mathrm{pH}$ growth from 8.6 to 9.08. In addition to the results above mentioned, further studies identified $\mathrm{pH}$ values around 9 as the most favorable for struvite precipitation [48], as summarized in Tables 1 and 2. Such a condition can be justified by considering that, as $\mathrm{pH}$ continues to grow above $\mathrm{pH} 9$, the MAP precipitation can be hindered since the availability of ammonium ion will decrease, due to its conversion into ammonia gas, while the permanence of phosphate ions in the solution notably increase [32,49]. 
Table 1. Operating conditions and nutrients recovery efficiencies identified in some works that used stirred tank reactors (STR) for struvite precipitation.

\begin{tabular}{|c|c|c|c|c|c|c|c|c|c|c|c|c|c|}
\hline Reference & $\begin{array}{l}\text { Wastewater } \\
\text { Influent }\end{array}$ & $\begin{array}{l}\text { Reactor } \\
\text { Typology }\end{array}$ & $\begin{array}{l}\text { Reactor } \\
\text { Volume }\end{array}$ & $\begin{array}{c}\text { Hydraulic } \\
\text { Retention } \\
\text { Time (HRT) }\end{array}$ & $\begin{array}{l}\text { Reaction } \\
\text { Time }\end{array}$ & Mixing & $\begin{array}{c}\mathrm{pH} \\
\text { Control }\end{array}$ & $\mathrm{pH}$ & $\begin{array}{l}\mathrm{Mg} \\
\text { Source }\end{array}$ & $\begin{array}{c}\mathbf{P} \\
\text { Source }\end{array}$ & $\mathrm{N}: M g: P$ & P-Removal & N-Removal \\
\hline & & & $\mathbf{L}$ & $\min$ & $\min$ & rpm & & & & & & $\%$ & $\%$ \\
\hline [1] & Landfill leachate & Batch & 1 & & 30 & & $\mathrm{NaOH}$ & 9 & $\mathrm{MgO}$ & $\mathrm{H}_{3} \mathrm{PO}_{4}$ & $1: 2: 1$ & $\approx 100$ & 95 \\
\hline [28] & $\begin{array}{c}\text { Synthetic } \\
\text { wastewater }\end{array}$ & Batch & 21 & 630 & & & $\mathrm{NaOH}$ & 8.7 & $\mathrm{MgCL}_{2} \cdot 6 \mathrm{H}_{2} \mathrm{O}$ & $\mathrm{NH}_{4} \mathrm{H}_{2} \mathrm{PO}_{4}$ & 2.4:09:1 & 81.40 & \\
\hline [33] & Sewage sludge & Batch & 0.25 & & 30 & 250 & $\mathrm{NaOH}$ & 9 & $\mathrm{MgCL}_{2} \cdot 6 \mathrm{H}_{2} \mathrm{O}$ & $\mathrm{H}_{3} \mathrm{PO}_{4}$ & 1.5:1:1 & 95 & 89.35 \\
\hline [41] & Landfill leachate & Batch & 4.8 & & 15 & 300 & $\mathrm{NaOH}$ & 9 & Seawater bittern & Bone meal & 1:1.1:1.1 & 99 & 95 \\
\hline [44] & Anaerobic digestate & Batch & 0.25 & & 15 & 300 & $\mathrm{NaOH}$ & 9 & Seawater bittern & Bone meal & 1:1.3:1.3 & 99 & 91 \\
\hline [50] & $\begin{array}{c}\text { Pretreated landfill } \\
\text { leachate }\end{array}$ & Batch & 0.4 & & 1 & 300 & $\mathrm{NaOH}$ & 9 & Seawater bittern & Bone meal & 1:1.3:1.3 & 99 & 90 \\
\hline [51] & Landfill leachate & Batch & 0.5 & & 30 & & $\mathrm{NaOH}$ & 9 & $\mathrm{MgCL}_{2} \cdot 6 \mathrm{H}_{2} \mathrm{O}$ & $\mathrm{Na}_{2} \mathrm{HPO}_{4}$ & 1:1:1 & & 92 \\
\hline [52] & Landfill leachate & Batch & 1 & & 3 & 200 & $\mathrm{NaOH}$ & 9 & $\mathrm{MgCL}_{2} \cdot 6 \mathrm{H}_{2} \mathrm{O}$ & $\mathrm{KH}_{2} \mathrm{PO}_{4}$ & 1:1.2:1.2 & $\approx 86$ & $\approx 99$ \\
\hline [53] & $\begin{array}{l}\text { Synthetic swine } \\
\text { wastewater }\end{array}$ & Continuous & 5 & 10 & 180 & & $\mathrm{NaOH}$ & 9 & $\mathrm{MgCL}_{2} \cdot 6 \mathrm{H}_{2} \mathrm{O}$ & $\mathrm{KH}_{2} \mathrm{PO}_{4}$ & 1:1.2:1.1 & $\approx 98.9$ & $\approx 85$ \\
\hline [54] & $\begin{array}{l}\text { Wastewater } \\
\text { treatment liquors }\end{array}$ & Batch & 1 & & 240 & 120 & Aeration & 8.5 & $\mathrm{MgO}$ & & $-: 2.5: 1$ & $\approx 90$ & \\
\hline [55] & $\begin{array}{l}\text { Anaerobic digestion } \\
\text { supernatant }\end{array}$ & Batch & 1 & & 60 & 300 & $\mathrm{NaOH}$ & 10 & $\mathrm{MgCl}_{2} \cdot 6 \mathrm{H}_{2} \mathrm{O}$ & $\mathrm{Na}_{2} \mathrm{HPO}_{4}$ & 7.7:1:1 & $>90$ & 29 \\
\hline [56] & Synthetic urine & Continuous & 20.55 & 261 & & 400 & $\mathrm{NaOH}$ & 8.8 & $\mathrm{MgCl}_{2} \cdot 6 \mathrm{H}_{2} \mathrm{O}$ & $\mathrm{KH}_{2} \mathrm{PO}_{4}$ & $4.3: 1: 1$ & 90 & \\
\hline [57] & $\begin{array}{c}\text { Synthetic } \\
\text { wastewater }\end{array}$ & Continuous & 2.4 & 125 & 83 & 500 & $\mathrm{NaOH}$ & 8.5 & $\mathrm{MgSO}_{4}$ & $\mathrm{Na}_{2} \mathrm{HPO}_{4}$ & 9.4:1:1 & 88 & \\
\hline [58] & Raw swine slurry & Batch & 0.35 & & 240 & & $\mathrm{NaOH}$ & 10 & $\mathrm{MgO}$ & $\mathrm{H}_{3} \mathrm{PO}_{4}$ & $1: 1: 1$ & 80 & 77 \\
\hline [59] & $\begin{array}{c}\text { Anaerobically } \\
\text { digested manure }\end{array}$ & Batch & 1 & & 60 & & $\mathrm{NaOH}$ & 8.7 & $\mathrm{MgCL}_{2} \cdot 6 \mathrm{H}_{2} \mathrm{O}$ & & $-: 1.5: 1$ & 80 & \\
\hline$[60]$ & $\begin{array}{l}\text { Anaerobically } \\
\text { digested centrate }\end{array}$ & Batch & 1 & & 30 & & & 9 & $\mathrm{MgO}$ & & 30.7:1.1:1 & $>90$ & \\
\hline [61] & Landfill leachate & Batch & 1 & & & 125 & $\mathrm{NaOH}$ & 8.5 & $\mathrm{MgCL}_{2} \cdot 6 \mathrm{H}_{2} \mathrm{O}$ & $\mathrm{H}_{3} \mathrm{PO}_{4}$ & 1:1:1 & & 72 \\
\hline [62] & Synthetic urine & Batch & 0.4 & & 30 & 200 & $\mathrm{NaOH}$ & 9 & $\mathrm{MgO}$ & & 1:1.4:1 & 96.70 & \\
\hline [63] & Synthetic solution & Batch & 1 & & 20 & 150 & Aeration & $9-10$ & Seawater bittern & $\mathrm{KH}_{2} \mathrm{PO}_{4}$ & $1: 1: 1$ & $>96$ & $>88$ \\
\hline
\end{tabular}


Table 2. Operating conditions and nutrients recovery efficiencies identified in some works that used fluidized bed reactors (FBR) for struvite precipitation.

\begin{tabular}{|c|c|c|c|c|c|c|c|c|c|c|c|c|c|c|c|}
\hline Reference & $\begin{array}{l}\text { Wastewater } \\
\text { Influent }\end{array}$ & $\begin{array}{c}\text { Seed } \\
\text { Material }\end{array}$ & $\begin{array}{l}\text { Reactor } \\
\text { Volume }\end{array}$ & Flowrate & HRT & pH Control & Mg:P & $\begin{array}{c}\text { Mg } \\
\text { Source }\end{array}$ & $\mathrm{pH}$ & $\begin{array}{l}\text { Airflow } \\
\text { Rate }\end{array}$ & $\begin{array}{c}\mathrm{P} \\
\text { Removal }\end{array}$ & $\begin{array}{c}\text { Recovered } \\
\text { Struvite }\end{array}$ & $\begin{array}{l}\text { Grain } \\
\text { Size }\end{array}$ & $\begin{array}{c}\text { Grain } \\
\text { Retention } \\
\text { Time }\end{array}$ & $\begin{array}{l}\text { Upflow } \\
\text { Velocity }\end{array}$ \\
\hline & & & $\mathrm{L}$ & $\mathrm{L} / \mathrm{h}$ & $\mathbf{h}$ & & & & & $\mathrm{m}^{3} / \mathrm{h}$ & $\%$ & $\mathrm{~kg} / \mathrm{m}^{3}$ & $\mathrm{~mm}$ & $\mathrm{~d}$ & $\mathrm{~cm} / \mathrm{min}$ \\
\hline [25] & $\begin{array}{c}\text { Synthetic } \\
\text { wastewater }\end{array}$ & Struvite & 1.35 & 0.72 & 1.4 & $\mathrm{NaOH}$ & $1.3: 1$ & $\mathrm{MgCl}_{2} \cdot 6 \mathrm{H}_{2} \mathrm{O}$ & 9.5 & & 95.8 & & & & \\
\hline [30] & $\begin{array}{l}\text { Anaerobic } \\
\text { digester } \\
\text { centrate }\end{array}$ & Struvite & 90 & 180 & 0.075 & & $1.3: 1$ & $\mathrm{MgCl}_{2} \cdot 6 \mathrm{H}_{2} \mathrm{O}$ & 8.2 & & $80 \%$ & & $0.5-3.5$ & & \\
\hline [64] & $\begin{array}{l}\text { Anaerobic } \\
\text { digester } \\
\text { supernatant }\end{array}$ & Struvite & $24.5 / 28.3$ & $18-36$ & $0.75-1.5$ & & $3.3: 1$ & $\mathrm{MgCl}_{2} \cdot 6 \mathrm{H}_{2} \mathrm{O}$ & $7.6-8.4$ & & $>85 \%$ & & $0.5-4.75$ & 10 & \\
\hline [65] & $\begin{array}{c}\text { Synthetic } \\
\text { wastewater }\end{array}$ & & $24.5 / 28.3$ & & & $\mathrm{NaOH}$ & $1.6: 1$ & & 7.9 & & $>90 \%$ & & $2.5-4$ & & \\
\hline [66] & Urine & & 2.6 & & 2 & Aeration & $1.3: 1$ & Seawater & & 0.06 & $>98.7 \%$ & & $0.036-0136$ & $4-5$ & \\
\hline [67] & $\begin{array}{l}\text { Wastewater } \\
\text { Anaerobic }\end{array}$ & Struvite & & & & $\mathrm{Mg}(\mathrm{OH})_{2}$ & $1: 1$ & $\mathrm{Mg}(\mathrm{OH})_{2}$ & $8.2-8.8$ & & $>90 \%$ & 0.087 & $0.5-1$ & 10 & \\
\hline [68] & $\begin{array}{l}\text { digester } \\
\text { centrate }\end{array}$ & Struvite & $24.5 / 28.3$ & & 0.074 & $\mathrm{NaOH}$ & $1.3: 1$ & $\mathrm{MgCl}_{2} \cdot 6 \mathrm{H}_{2} \mathrm{O}$ & 8.2 & & $85 \%$ & & $0.5-3.5$ & & 410 \\
\hline [69] & $\begin{array}{c}\text { Anaerobic } \\
\text { liquor }\end{array}$ & $\begin{array}{l}\text { Quartz } \\
\text { sand }\end{array}$ & & 18000 & & Aeration & & $\mathrm{MgCl}_{2} \cdot 6 \mathrm{H}_{2} \mathrm{O}$ & 8.2 & 21 & $83.30 \%$ & 0.43 & 0.7 & & \\
\hline [70] & $\begin{array}{c}\text { Synthetic } \\
\text { wastewater }\end{array}$ & & 9.5 & 1.8 & 10 & $\mathrm{NaOH}$ & $1.75: 1$ & $\mathrm{MgCl}_{2} \cdot 6 \mathrm{H}_{2} \mathrm{O}$ & 9.5 & & $>90 \%$ & & & & \\
\hline [71] & $\begin{array}{c}\text { Synthetic } \\
\text { wastewater }\end{array}$ & Struvite & 2 & 4 & 4.1 & $\mathrm{NaOH}$ & $1.6: 1$ & $\mathrm{MgCl}_{2} \cdot 6 \mathrm{H}_{2} \mathrm{O}$ & 8.5 & & $83 \%$ & & & & \\
\hline [72] & $\begin{array}{c}\text { Synthetic } \\
\text { wastewater }\end{array}$ & Struvite & 12 & 6 & 2 & Aeration & 1:1 & $\mathrm{MgCl}_{2} \cdot 6 \mathrm{H}_{2} \mathrm{O}$ & 8 & 0.042 & $>91 \%$ & 0.025 & $0.4-2$ & & \\
\hline [73] & $\begin{array}{l}\text { Raw water } \\
\text { Swine }\end{array}$ & struvite & & 279.17 & & Aeration $/ \mathrm{NaOH}$ & 1.9:1 & $\mathrm{MgCl}_{2} \cdot 6 \mathrm{H}_{2} \mathrm{O}$ & 8.4 & & $92 \%$ & & $0.55-1.18$ & $3-4$ & \\
\hline [74] & $\begin{array}{l}\text { lagoon } \\
\text { liquid }\end{array}$ & Struvite & 30.15 & 568 & 0.05 & $\mathrm{MgOH}_{2}$ & & $\mathrm{MgO}$ & 8 & & 70 & & $0.25-1.19$ & & \\
\hline
\end{tabular}


On the other hand, other works identified higher $\mathrm{pH}$ values as optimal for struvite precipitation. In particular, Ohlinger et al. [42] found the minimum solubility at $\mathrm{pH} 10.3$ including the presence of magnesium phosphate complex to predict the struvite precipitation in wastewater. Shin and Lee [75] detected a continuous decrease in $\mathrm{PO}_{4}{ }^{3-}$ and $\mathrm{NH}_{4}{ }^{+}$concentration due to struvite precipitation as the $\mathrm{pH}$ was raised to 10.5. Siciliano et al. [50] determined that a $\mathrm{pH}$ value of 10 was the best condition for the struvite precipitation in pretreated landfill leachate. The differences in the literature reports may be related to the composition of treated wastewater which was different from one work to another. Indeed, any modification in wastewater chemistry results in differences in ionic strength and activity which, in addition to the other factors, affect the struvite precipitation potential [49]. Furthermore, the type of ionic species in the wastewater also influence the formation of MAP crystals. Indeed, as better discussed in Section 2.5, the presence of competitive ions $\left(\mathrm{Ca}^{2+}, \mathrm{Na}^{+}, \mathrm{K}^{+}, \mathrm{Al}^{3+}, \mathrm{Fe}^{3+}\right.$, etc.), in connection with the $\mathrm{pH}$ values, has a great influence on the precipitation process. For example, in the presence of high concentrations of calcium $\left(\mathrm{Ca}^{2+}\right)$, a pH value higher than 10 could cause the formation of a metastable form of hydroxyapatite and only a small part of struvite [76].

Therefore, on the basis of these considerations, it can be stated that a unique $\mathrm{pH}$ for struvite precipitation cannot be assumed. This means that the $\mathrm{pH}$ value to optimize the removal and recovery of nutrients in the form of MAP should be identified through direct investigations on wastewater to be treated.

\subsection{Effects of Molar Ratios on Struvite Formation}

According to reaction 1, struvite nucleation occurs when $\mathrm{Mg}^{2+}, \mathrm{NH}_{4}{ }^{+}$, and $\mathrm{PO}_{4}{ }^{3-}$ are present in equimolar concentration in solution [12,37]. Therefore, the availability of the three components is a key factor in the formation of struvite crystals. Generally, there is a significant difference in the molar concentrations of $\mathrm{Mg}^{2+}, \mathrm{PO}_{4}{ }^{3-}$, and $\mathrm{NH}_{4}{ }^{+}$ions in real effluents. In particular, many wastewaters are characterized by higher molar amounts of ammonium with respect to the other struvite constituents. This difference is very marked in aqueous waste, such as leachate and digestate, derived from anaerobic biological processes. Only in rare cases, such as the liquid phases of supercritical gasification processes, there is a nitrogen deficit compared to the content of $\mathrm{PO}_{4}{ }^{3-}$ and $\mathrm{Mg}^{2+}$ [8]. Clearly, the struvite precipitation aimed at the contextual removal of phosphorus and ammonium is more expensive because, to reach the stoichiometric molar ratios, the addition of reagents, both of magnesium and phosphorus, is required. In this case the process efficiency is directly linked to the molar ratios among the three elements N:Mg:P. On the contrary, the struvite precipitation aimed at the exclusive removal and recovery of phosphorus is a more sustainable process. In fact, due to the excess of ammonium, only the addition of magnesium is, eventually, required and the process depends mainly on the Mg:P molar ratio.

Despite equal molar amounts required for struvite precipitation, the reagents should be overdosed regarding the theoretical value, since in real wastewater there are competitive ions such as, $\mathrm{Ca}^{2+}, \mathrm{Na}^{+}$, $\mathrm{K}^{+}, \mathrm{Al}^{3+}, \mathrm{Fe}^{3+}$, etc., which can react with $\mathrm{Mg}^{2+}$ and $\mathrm{PO}_{4}{ }^{3-}$ ions reducing their availability for MAP formation $[2,12,77-79]$.

The optimal molar ratios must be assessed case-by-case as it depends heavily on the chemical-physical characteristics of wastewater. The dosages also depend on the type of chemicals used as sources of magnesium and phosphorus in the treatment. For these reasons, regarding the most favorable molar ratios, a great divergence among the literature reports can be found (Tables 1 and 2). In particular, in the treatment of landfill leachate, $\mathrm{NH}_{4}{ }^{+}$removals of about $90 \%$ were obtained with soluble analytical-grade reagents $\left(\mathrm{MgCl}_{2} \cdot 6 \mathrm{H}_{2} \mathrm{O}, \mathrm{Na}_{2} \mathrm{HPO}_{4} \cdot 12 \mathrm{H}_{2} \mathrm{O}\right)$ that were dosed at the theoretical stoichiometric amounts [51]. Also Kabdaşli et al. [2] obtained a very high $\mathrm{NH}_{4}{ }^{+}$removal yield, around to $94 \%$, by using pure reagents at dosages $(\mathrm{N}: \mathrm{Mg}: \mathrm{P}=1: 1: 1.05)$ close to the stoichiometric values. On the contrary, other works, in which unconventional reagents were exploited, found that greater dosages are necessary. Specifically, Di Iaconi et al. [1] using $\mathrm{MgO}$ as source of magnesium observed an increase of ammonia removal, from $67 \%$ up to $95 \%$, by doubling the amount of magnesium from 
the stoichiometric value (1:1:1) to a molar ratios N:Mg:P of 1:2:1. Siciliano et al. [44,50] detected efficiencies near to $90 \%$ exploiting seawater bittern and bone meal, as sources of $\mathrm{Mg}^{2+}$ and $\mathrm{PO}_{4}{ }^{3-}$, respectively, dosed at $\mathrm{N}: \mathrm{Mg}: \mathrm{P}=1: 1.3: 1.3$, in the treatment both of pretreated landfill leachate and cattle manure digestate. On the other hand, in another work conducted using the same reagents, Siciliano [41] found that molar ratios of $\mathrm{N}: \mathrm{Mg}: \mathrm{P}=1: 1.1: 1.1$ were sufficient to reach the best efficiency for ammonium abatement in methanogenic landfill leachate. Kim et al. [52] proved that the MAP formation is also influenced by the sequence of chemicals addition. In particular, with amounts of $\mathrm{N}: \mathrm{Mg}: \mathrm{P}=1: 1 \cdot 2: 1.2$, the best performance for ammonium removal and high struvite deposits were reached by dosing the magnesium and phosphate reagents prior to $\mathrm{pH}$ setting [52]. Siciliano et al. [44] confirmed these statements and observed that the $\mathrm{pH}$ correction after the $\mathrm{Mg}^{2+}$ and $\mathrm{PO}_{4}{ }^{3-}$ dosage reduces the precipitation of compounds different from struvite, such as calcium phosphates. Anyhow, the formation of some additional compounds, generally phosphates insoluble salts, cannot be avoided. For these reasons, higher abatements of phosphorus, with respect to the ammonium removals, were often observed [4,52].

In the treatment aimed at phosphorus removal and recovery, many works claimed the importance to apply a Mg:P molar ratio higher than the stoichiometric value [53,80-82]. Quintana et al. [54] found a strong influence of $\mathrm{Mg}: \mathrm{P}$ ratio on the abatement of phosphates amount and the major removal was detected when pure $\mathrm{MgO}$ was dosed at a molar ratio of 1.5. Moreover, the authors observed that the increase of the molar ratio promoted the removal rate growth [80]. Nelson et al. [81] detected a positive effect on phosphorus removal by increasing the Mg:P dose from 1 to 1.6. Furthermore, according to the authors, with the increase of $\mathrm{Mg}: \mathrm{P}$ ratio the $\mathrm{PO}_{4}{ }^{3-}$ abatement can be obtained with a smaller increase in $\mathrm{pH}$ [81]. This could permit satisfactory phosphorus removals with limited addition of alkali avoiding potentially adverse effects of high $\mathrm{pH}$ or ammonia volatilization [81]. Marti et al. [82] argued that the increase of $\mathrm{Mg}^{2+}$ availability decreases the Ca:Mg molar ratio, which favors the precipitation of struvite rather than calcium phosphates. In agreement with this consideration, Jaffer et al. [83] affirmed that with Mg:P addition lower than 1.05:1 the precipitate resulted in a mixture of struvite and hydroxyapatite and a $\mathrm{Mg}^{2+}$ dosage of 1.3:1 was suggested for full scale applications. However, an excess of $\mathrm{Mg}^{2+}$ can cause the formation of magnesium phosphates, reducing the precipitation of struvite. In particular, Korchef et al. [21] observed the phosphate removal caused by MAP precipitation for $\mathrm{Mg}: \mathrm{P}$ molar ratio $\leq 4$ and by newberyite $\left(\mathrm{MgHPO}_{4} \cdot 3 \mathrm{H}_{2} \mathrm{O}\right)$ and cattiite $\left(\mathrm{Mg}_{3}\left(\mathrm{PO}_{4}\right)_{2} \cdot 22 \mathrm{H}_{2} \mathrm{O}\right)$ formation for $\mathrm{Mg}: \mathrm{P}=5$.

\subsection{Temperature and Struvite Solubility}

Temperature considerably affects the solubility, the morphology of struvite crystals, as well as their formation and dissolution. Many studies considered the range between $25{ }^{\circ} \mathrm{C}$ and $35^{\circ} \mathrm{C}$ as optimal for struvite precipitation. Crutchik and Garrido [84] showed that the temperature growth from $25^{\circ} \mathrm{C}$ to $30^{\circ} \mathrm{C}$ and $35^{\circ} \mathrm{C}$ caused the increase of struvite solubility product and promoted both the presence of crystals with a lesser degree of purity and their dissolution [85]. According to Moussa et al. [86], as the temperature increases from $14{ }^{\circ} \mathrm{C}$ to $35^{\circ} \mathrm{C}$ the ionic activities and the supersaturation coefficient increase, thus reducing the efficiency of crystals formation by more than $30 \%$. Other studies stated that, as the temperature increased from $25^{\circ} \mathrm{C}$ to $37^{\circ} \mathrm{C}$, crystals changed from a prismatic rectangular shape at $25^{\circ} \mathrm{C}$ to a dendritic structure $[79,87]$. The struvite solubility, in combination with the temperature, is largely affected by the chemical composition of the solution. In effect, several studies assessed how the solubility product of struvite undergoes variations with the characteristics of wastewater in which the precipitation occurs. Aage et al. [88] stated that in synthetic aqueous solution the struvite solubility tends to grow in response to the temperature increase up to $50{ }^{\circ} \mathrm{C}$, and then it decreases assuming a value equal to $2.5 \times 10^{-13}$ at $65^{\circ} \mathrm{C}$. A lower value, of $5.49 \times 10^{-14}$, was calculated by Ohlinger et al. [42] at $\mathrm{pH} 10.3$ and $25^{\circ} \mathrm{C}$ by predicting the struvite formation in digestion. On the other hand, Loewenthal et al. [89], studying the solubility of struvite in a digestate, determined a $\mathrm{K}_{\mathrm{sp}}$ value equal to $2.5 \times 10^{-13}$. Studies conducted by Gunay et al. [90] showed that 
the solubility of struvite in landfill leachate decreased by $80 \%$ in response to $\mathrm{pH}$ increase from 6.5 to 8.5. Furthermore, the solubility of struvite can be also influenced by the presence of other ions such as $\mathrm{Ca}^{2+}, \mathrm{CO}_{3}{ }^{2-}$ [91]. The presence of competitive ions is a main problem in digestates where the conspicuous amount of calcium can interfere with the struvite formation processes by subtracting phosphate ions [92]. The level of oversaturation also affects the crystallization process as it causes a decrease of the nucleation time and growth [93]. The extreme variability of the $\mathrm{K}_{\mathrm{sp}}$ values reported in literature is shown in the following Table $3[79,84,88,94,95]$.

Table 3. $\mathrm{K}_{\mathrm{SP}}$ values reported in different studies.

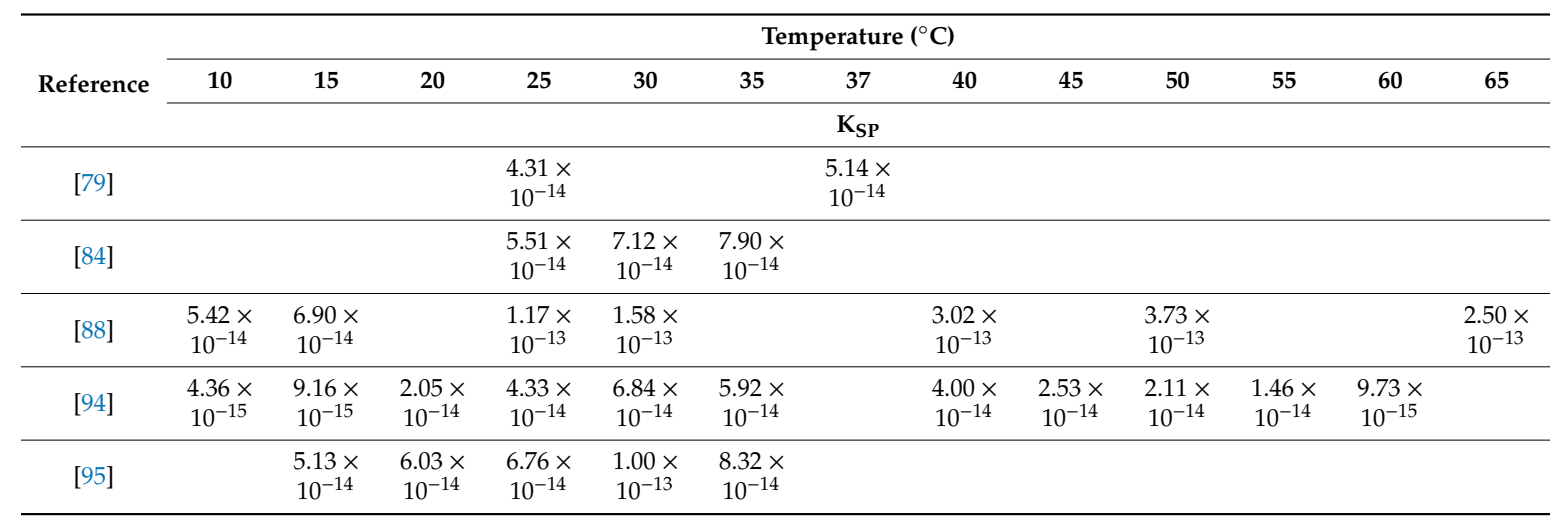

\subsection{Presence of Competitive Ions}

The presence in solution of competitive ions, such as $\mathrm{Ca}^{2+}, \mathrm{Na}^{+}, \mathrm{K}^{+}, \mathrm{CO}_{3}{ }^{2-}, \mathrm{HCO}_{3}{ }^{-}$, etc., can strongly influence the struvite crystals nucleation and growth [12]. Kabdaşl1 et al. [2] highlighted the negative impact of the presence of these ions both on the induction time and on the morphology and size of the struvite crystals. Mono-valent ions such as $\mathrm{Na}^{+}$and $\mathrm{K}^{+}$could compete with ammonium in the formation of struvite compounds promoting the formation of $\mathrm{MgNaPO}_{4}$ and $\mathrm{MgKPO}_{4}$ instead of MAP. In some works, the presence of potassium salts, such as $\mathrm{MgKPO}_{4}$, into the recovered solid of MAP precipitation process was detected [1,64]. However, according to other studies the production of $\mathrm{MgKPO}_{4}$ can take place only in the case of low $\mathrm{NH}_{4}{ }^{+}$amounts $[29,82]$. Na salts were recovered in presence of a high concentration of sodium in the treating mixture [41]. Struvite formation can also be hindered by high alkalinity values. In particular, $\mathrm{HCO}_{3}{ }^{-}$and $\mathrm{CO}_{3}{ }^{2-}$ are able to bond $\mathrm{Mg}^{2+}$ and $\mathrm{NH}_{4}{ }^{+}$ ions, which leads to the formation of stable aqueous phases of $\mathrm{MgCO}_{3}, \mathrm{Mg}\left(\mathrm{HCO}_{3}\right)_{2}$, and $\mathrm{NH}_{4} \mathrm{HCO}_{3}$, and, therefore, reduces the availability of two constituents for struvite nucleation [47]. In addition to the effects mentioned above, the main adverse impact on MAP precipitation is linked to presence of $\mathrm{Ca}^{2+}$ ions. Indeed, high levels of calcium in the solution can completely obstruct struvite nucleation [91]. Furthermore, when calcium ions interact with the orthophosphate, the production of apatite and hydroxyapatite can take place. These mechanisms subtract the phosphate ions from the solution and, therefore, reduce the struvite formation $[85,96,97]$. The relationship through which the calcium binds to the phosphate in the form of hydroxyapatite is shown below:

$$
5 \mathrm{Ca}^{2+}+3 \mathrm{PO}_{4}^{3-}+\mathrm{H}_{2} \mathrm{O} \rightarrow \mathrm{Ca}_{5}\left(\mathrm{PO}_{4}\right)_{3} \mathrm{OH}+\mathrm{H}^{+}
$$

Since calcium represents an ion that competes with magnesium, several studies were carried out to evaluate the influence of calcium concentration on struvite formation $[77,92,98]$. In particular, according to some works, a Ca:Mg molar ratio lower than 0.2 does not affect the struvite production and it allows to recover a solid with high standards of purity, while values greater than 0.2 reduce struvite quality and slow down the nucleation process [77]. In particular, a $\mathrm{Ca}: \mathrm{Mg}$ ratio between 0.5 and 0.75 considerably influences struvite formation and its purity degree, while values greater than 1 prevent struvite nucleation [76]. Le Corre et al. [92] also observed that wastewaters with a 
molar ratio $\mathrm{Ca}: \mathrm{Mg}$ higher than 1 avoided the struvite formation causing the production of amorphous calcium phosphates. The inhibitory effects of $\mathrm{Ca}^{2+}$ ions can be mitigated by dosing excess $\mathrm{Mg}^{2+}$ to force out the precipitation of struvite [98]. However, a $\mathrm{Mg}^{2+}$ overdose itself can induce the precipitation of magnesium phosphates and, moreover, it increases the treatment costs. Chelation treatments, to form complexes with $\mathrm{Ca}^{2+}$, improved the MAP purity in anaerobically digested dairy manure [98]. Indeed, chelating agents such as EDTA, whose stability constant for $\mathrm{Ca}^{2+}$ is greater than two orders of magnitude compared to that for $\mathrm{Mg}^{2+}$, allow reducing the concentration of calcium in the wastewater without affecting the concentration of phosphorus [97]. Nevertheless, struvite crystals morphology in the chelation process was inconsistent compared to other recovered precipitates [98]. Furthermore, chelating chemicals addition results in a significant cost increase and their discharge with the wastewater produces additional environmental impacts [98]. As an alternative to the use of chelating agents, $\mathrm{CaCO}_{3}$ precipitation could be a suitable pretreatment to limit $\mathrm{Ca}^{2+}$ interference and keep phosphates in solution for MAP precipitation [98]. In this process, the $\mathrm{pH}$ is set to values between 9.5 and 10 in order to promote the formation of insoluble $\mathrm{CaCO}_{3}$. The precipitation of this salt reduces the calcium content and, by subtracting $\mathrm{CO}_{3}{ }^{2-}$ ions, also reduces the wastewater alkalinity, which itself could hinder the struvite formation [99,100]. In this treatment, supplemental magnesium ions should be dosed after $\mathrm{CaCO}_{3}$ precipitation. Studies conducted on digestates by Huchzermeier and Tao et al. [98] proved that calcium can be recovered beforehand as calcium carbonate, keeping the content of orthophosphates in solution. Precipitation of $\mathrm{CaCO}_{3}$ can be also promoted by setting the $\mathrm{pH}$ to the required values through insufflation of atmospheric air into the solution, so as to induce the degasification of dissolved $\mathrm{CO}_{2}[22,99,100]$. This application limits the consumption of chemicals for $\mathrm{pH}$ correction.

\subsection{Reagents Used for Struvite Precipitation}

As previously discussed, the struvite precipitation processes, in general, require the addition of a proper amount of magnesium and, if ammonium must be removed, phosphorus chemicals. The quantities of these reagents must be evaluated according to the wastewater chemical-physical characteristics. Moreover, the supplementation of alkaline compounds is often necessary to set the $\mathrm{pH}$ to the values able to minimize the struvite solubility $[52,90,101]$. Also in this case, the dosage depends on the wastewater properties and, furthermore, on the quantity of magnesium and/phosphorus reagents to be added. Indeed, many compounds of magnesium and phosphorus have an acidic behavior once dissolved in an aqueous solution and, therefore, their dosages increase the consumption of alkaline compounds for $\mathrm{pH}$ setting [44]. Obviously, the choice of reagents type has a great impact on process effectiveness. Indeed, the reagents must be effective, simple to use and must not contain elements able to inhibit the struvite nucleation process. Furthermore, to limit the economic burden of the treatment, it is essential to identify and to evaluate the applicability of low-cost unconventional reagents $[54,102,103]$. Some studies verified the effectiveness of low-cost magnesium-based compounds [90], while few were focused on the application of unconventional phosphorus-based reagents; but these ones are more expensive and their consumption generally represents the main cost of the whole process [1]. As an alternative to the use of external reagents of magnesium and phosphorus, a research topic concerns the reuse of struvite as a reactant in sequential treatments [104-106]. Some works also experimented with the use of alternative reagents and methods for $\mathrm{pH}$ setting $[47,107]$. In the following sections, an overview on the main chemicals and techniques that were investigated and applied for struvite precipitation processes is reported.

\subsubsection{Magnesium Sources}

In the treatment for MAP precipitation, pure reagents such as $\mathrm{MgSO}_{4}, \mathrm{MgCl}_{2}, \mathrm{Mg}(\mathrm{OH})_{2}$, and $\mathrm{MgO}$ are commonly used $[65,99,103]$. Some of these salts, such as $\mathrm{MgSO}_{4}$ and $\mathrm{MgCl}_{2}$, have the advantage of being very soluble allowing to recover a precipitate with a high purity degree [3]. Due to their easy management, they were used in many studies through which the kinetics of the nucleation process have 
been assessed $[79,94,108]$. They are also exploited in full-scale applications such as the Ostara Pearl ${ }^{\circledR}$, the Phospaq, the Seaborne, and the AirPrex processes. However, despite their benefits, the dosage of $\mathrm{MgSO}_{4}$ and $\mathrm{MgCl}_{2}$ causes a marked increase in $\mathrm{Cl}^{-}$and $\mathrm{SO}_{4}{ }^{2-}$ concentrations, with consequent deterioration of the effluent quality [3,109].

The use of $\mathrm{MgO}$, instead, does not produce any increase in solution salinity. However, magnesium oxide has low solubility in water. Therefore, to effectively feed the right quantity of $\mathrm{Mg}^{2+}$ ions in solution, it is necessary to pre-treat $\mathrm{MgO}$ by means of acid dissolution which complicates the precipitation process [106]. If phosphorus addition is required, $\mathrm{MgO}$ is, generally, dissolved through the supplementation of phosphoric acid $[1,3,51,110]$. However, for given N:Mg:P ratios, the addition of $\mathrm{MgO}$ and $85 \% \mathrm{H}_{3} \mathrm{PO}_{4}$ showed the poorest performance among other combinations of soluble chemicals, in the treatment of effluent of upflow anaerobic sludge blanket (UASB)reactors treating poultry manure wastewater [110]. Li and Zhao [51] detected analogous findings by comparing some chemical combinations in the removal of $\mathrm{NH}_{4}{ }^{+}$from landfill leachate. These results can be attributed to the low $\mathrm{MgO}$ solubility which results in a low global efficiency [110]. In effect, in some studies it was necessary to double the dosage of $\mathrm{MgO}$, with respect to the stoichiometric ratio, to achieve ammonium removal efficiency of about $95 \%[1,54,80]$. This overdose, clearly, notably affects the total cost for struvite production. Similar to the findings obtained with magnesium oxide, $\mathrm{Mg}(\mathrm{OH})_{2}$ proved to be a less efficient $\mathrm{Mg}^{2+}$ source, in terms of $\mathrm{NH}_{4}{ }^{+}$removal, compared to soluble magnesium reagents [32]. Moreover, by using $\mathrm{Mg}(\mathrm{OH})_{2}$, the $\mathrm{pH}$ value and the $\mathrm{Mg}$ :P molar ratio cannot be controlled independently of each other [111].

Over the past years, struvite crystallization by exploiting a magnesium sacrificial anode as the source of $\mathrm{Mg}^{2+}$ has attained interest as a possible way for phosphorus removal and recovery. Kruk et al. [112] found that a high-purity magnesium alloy cast anode was very efficient in the recovery of struvite with high purity from water solutions, by using an electric current density of $45 \mathrm{~A} / \mathrm{m}^{2}$. Hug and Udert [113] obtained a P removal of $3.7 \mathrm{mgPcm}^{-1} \cdot \mathrm{h}^{-1}$ exploiting a sacrificial magnesium anode and applying a current density of $55 \mathrm{~A} / \mathrm{m}^{2}$. Song et al. [114] demonstrated that the presence of $\mathrm{Cl}^{-}$in the solution accelerates the $\mathrm{Mg}^{0}$ corrosion and facilitates the release of $\mathrm{Mg}^{2+}$.

Recently, Huang et al. [106] defined a novel approach for crystallization and precipitation of phosphate as MAP from swine wastewater using metal magnesium as $\mathrm{Mg}^{2+}$ source. The study was based on the reactions that the metallic magnesium undergoes in aqueous solutions. As a consequence of these reactions, the metallic $\mathrm{Mg}^{0}$ is oxidized to $\mathrm{Mg}^{2+}$ with production of $\mathrm{OH}^{-}$and $\mathrm{H}_{2}$. Therefore, the $\mathrm{Mg}^{0}$ corrosion plays two functions for struvite, formation by providing $\mathrm{Mg}^{2+}$ and raising the mixture $\mathrm{pH}$. The authors demonstrated that the process efficiency depends mainly on the magnesium metal dosage. With a $\mathrm{Mg}^{0}$ dose of $10 \mathrm{~g} / \mathrm{L}$ and a reaction time of $15 \mathrm{~min}$, phosphorus recovery efficiency of $96.3 \%$ was obtained [106]. The reaction system performance was further improved by coupling metallic $\mathrm{Mg}^{0}$ with graphite pellets and air bubbling [106]. In fact, the presence of graphite significantly accelerates the $\mathrm{Mg}^{0}$ corrosion and the air insufflation reduces the passivation of the metal's surface. An economic analysis indicated that the cost for dosing the $\mathrm{Mg}^{2+}$ through the corrosion of $\mathrm{Mg}^{0}$ metal was greater than that of using the $\mathrm{MgO}$, but was similar to those of using $\mathrm{MgCl}_{2}$ and $\mathrm{MgSO}_{4}$. The use of metal $\mathrm{Mg}^{0}$ was successfully applied very recently in the recovery of $\mathrm{P}$ content from livestock wastewater obtaining efficiency close to $98 \%$ [107].

In recent years, the scientific community has turned its attention to the use of low-cost magnesium sources. In particular, magnesite [90,115], bittern [77,103,116], seawater [66,117], and wood-ash [118], have been tested.

- Magnesite $\left(\mathrm{MgCO}_{3}\right)$ is a mineral rock particularly abundant in nature but its low solubility in aqueous solutions makes it necessary to apply adequate pretreatments. Gunay et al. [90] used magnesite $\left(\mathrm{MgCO}_{3}\right)$ to evaluate ammonium removal from landfill leachate. In particular, the magnesite was pretreated with $\mathrm{HCl}$ to obtain a sufficient quantity of magnesium in solution. Ammonium removal yields in the form of struvite were $91 \%$. The authors evaluated a reduction in the process costs of about $18.3 \%$ by using $\mathrm{MgCO}_{3}$ instead of $\mathrm{MgCl}_{2}$. However, a notable 
$\mathrm{HCl}$ addition was required to dissolve all the magnesium content of magnesite. In other studies, magnesite was calcined at high temperatures to produce a by-product (BMP), containing $\mathrm{MgO}$, exploitable as a magnesium source in the MAP precipitation processes $[54,80,105,115]$. Quintana et al. $[54,80]$ observed significantly lower performances in the struvite precipitation process using BMP produced from magnesite calcination compared to pure $\mathrm{MgO}$. This can be justified by considering that BMP has an available $\mathrm{Mg}^{2+}$ amount lower than of pure $\mathrm{MgO}[54,80,105,115]$. Moreover, BMP is generally characterized by greater particle sizes which slow down the reactivity $[54,80,105]$.

- Seawater has a magnesium content of about $146 \mathrm{kgMg} / \mathrm{m}^{3}$ and represents a low-cost source of magnesium exploitable for struvite precipitation [66]. Rubio-Rincón et al. [117] evaluated the use of seawater as a source of magnesium for phosphorus recovery through MAP formation from separate human urine. In particular, the seawater was mixed with non-hydrolyzed urine and hydrolyzed urine obtaining a 99\% phosphorus removal after 10 min with a Mg:P molar ratio equal to 3.3:1 [117]. Struvite formation was favored with a urine/seawater ratio of 1:1.7 [117]. However, problems linked to the use of seawater were the formation of fine crystals [66] and the co-precipitation of calcite in addition to struvite [119].

- Seawater bittern is a by-product obtained from sea salt manufacturing which contains mainly $\mathrm{MgCl}_{2}$ with small amounts of other inorganic compounds. Its $\mathrm{Mg}^{2+}$ content is notably higher than seawater and, therefore, it could represent a suitable low-cost source of magnesium [103]. The addition of bittern to a synthetic solution of swine wastewater was comparable to $\mathrm{MgCl}_{2}$ and seawater, as a magnesium ions source, in terms of phosphorus abatements [105]. The effectiveness of seawater bittern was also proved for the phosphate recovery in real swine wastewater [105]. Moreover, Siciliano et al. [41,44,50] found that seawater bittern can be efficiently used as a source of magnesium in the removal of $\mathrm{NH}_{4}{ }^{+}$through MAP precipitation from landfill leachates and digestate of calf manure.

- Combustion ashes. Sakthivel et al. [118] investigated the possible application of wood combustion ashes as an alternative source of magnesium to favor struvite precipitation. By applying the wood ashes to the urine, $87 \%$ of the incoming phosphorus was removed after a $0.5 \mathrm{~h}$ treatment, but the production of hydroxyapatite was mainly observed [118]. Other studies detected mostly the presence of calcium insoluble compounds in the precipitate obtained using fly ashes and calcined paper mill sludge in the treatment of anaerobic digestion reject water [120]. Moreover, due to the high presence of metal compounds in combustion ashes [3], the recovered precipitate is generally incompatible with the legislation for fertilizers.

\subsubsection{Phosphorus Sources}

For treatments aimed at the removal and recovery of $\mathrm{NH}_{4}{ }^{+}$from high polluting wastewater (leachates, digestates, urine, etc.), because of the great surplus of ammonium relative to the concentrations both of magnesium and phosphorus, the supplementation of phosphorus sources must be also provided [41,44,50,121].

Generally, $\mathrm{H}_{3} \mathrm{PO}_{4}$ and phosphate salts such as $\mathrm{Na}_{3} \mathrm{PO}_{4}, \mathrm{Na}_{2} \mathrm{HPO}_{4}$, or $\mathrm{NaH}_{2} \mathrm{PO}_{4}$ are exploited as P-based compounds [3]. These compounds allow very high ammonium removal yields and the production of struvite with high purity degree. However, the use of pure reagents results in the consumption of natural $P$ resources and makes the process very expensive. Indeed, the addition of phosphorus reagents generally results in the main cost of the entire treatment $[1,44,122]$. Therefore, it is necessary to identify unconventional and low-cost phosphorus sources effective in the struvite precipitation process. Currently, few studies have focused on the use of $P$ by-products $[41,44,50,121,122]$.

Huang et al. [121] conducted a study using waste phosphoric acid as a source of phosphorus for $\mathrm{NH}_{4}{ }^{+}$removal from landfill leachate. This work demonstrated that an ammonium removal similar to those achievable with pure phosphate salts could be obtained at $\mathrm{pH} 9$ and $\mathrm{N}: \mathrm{Mg}: \mathrm{P}$ ratio of 1:1.2:1. By coupling the $\mathrm{H}_{3} \mathrm{PO}_{4}$ waste with low-cost $\mathrm{MgO}$, as the magnesium source and as the alkali compound 
for $\mathrm{pH}$ correction, the $\mathrm{NH}_{4}{ }^{+}$removal yield was found to be $83 \%$ by dosing the $\mathrm{MgO}$ with $\mathrm{M}: \mathrm{Mg}: \mathrm{P}$ equal to 1:3:1 [121]. An economic analysis proved that the use of waste $\mathrm{H}_{3} \mathrm{PO}_{4}$ with the low-cost $\mathrm{MgO}$ can reduce the chemical costs by $68 \%$. However, the presence of $\mathrm{Al}^{3+}$ in the phosphoric acid waste can significantly hamper the struvite formation by competing for the phosphate ions [121].

Siciliano et al. $[41,44,50]$ used for the first time the bone meal, a by-product obtained from the thermal treatment of meat waste, as a low-cost source of phosphates for MAP precipitation. In Europe, the use of this by-product as a fertilizer is limited [123] and, as it is only suitable for a few alternative uses, it is usually landfilled $[124,125]$. Therefore, the utilization of bone meal for the struvite precipitation process is very profitable as it allows the recovery of its $\mathrm{P}$ content with the production of a more valuable compound which contains both $\mathrm{PO}_{4}{ }^{3-}$ and $\mathrm{NH}_{4}{ }^{+}$. The bone meal was coupled with the seawater bittern, as a $\mathrm{Mg}^{2+}$ source, for the ammonium recovery from methanogenic landfill leachates and calf manure digestates $[41,44,50]$.

To dissolve its phosphorus content, the bone meal was properly mixed in sulfuric acid solutions, which resulted in phosphorus concentrations between $68-80 \mathrm{gPO}_{4}{ }^{3-}-\mathrm{P} / \mathrm{L}[41,44,50] . \mathrm{H}_{2} \mathrm{SO}_{4}$ was used to limit the dissolution calcium content of bone meal, which remained mostly in the insoluble form as $\mathrm{CaSO}_{4}$. By coupling bone meal with seawater bittern, about $95 \%$ of $\mathrm{NH}_{4}{ }^{+}$content of raw landfill leachate and about $99 \%$ of $\mathrm{P}$, added for the treatment, were removed and recovered by applying molar ratios N:Mg:P equal to 1:1.1:1.1 [41]. With the same reactants, by treating digestates of calf manure, an $\mathrm{NH}_{4}{ }^{+}$abatement of about $90 \%$ and a P recovery of about $99 \%$ were reached at $\mathrm{pH} 9$ and with $\mathrm{N}: \mathrm{Mg}: \mathrm{P}=1: 1.3: 1.3[44]$.

Several bones' ashes were characterized by Darwish et al. who found that the ash derived from waste fish bones has the highest phosphorus level [122]. The phosphorus content of these ashes was extracted by means of $\mathrm{H}_{2} \mathrm{SO}_{4}$ and, thereafter, it was effectively applied for MAP precipitation. In particular, by treating wastewater more than $90 \%$ ammonium abatement and high purity MAP were obtained [122].

\subsubsection{Reactants for $\mathrm{pH}$ Correction}

Because struvite precipitation occurs in moderate basic conditions, alkaline reagents such as $\mathrm{NaOH}, \mathrm{MgO}, \mathrm{Mg}(\mathrm{OH})_{2}, \mathrm{KOH}$ are generally used to increase the $\mathrm{pH}$ to the optimum value $[67,126-128]$. Soluble compounds $(\mathrm{NaOH}, \mathrm{KOH})$ allow an easy and effective correction but they increase the salinity of solution and supply sodium and potassium that could interfere with struvite formation. On the other hand, magnesium oxide and hydroxide permit to increase the $\mathrm{pH}$ and, at the same time, they provide the $\mathrm{Mg}^{2+}$ ions required for MAP nucleation. However, due to their low solubility, these compounds must be dissolved in acids. Moreover, the $\mathrm{pH}$ setting and the addition of magnesium ions cannot be controlled separately. To reduce the cost connected to the consumption of alkaline compounds, recent studies showed that it is possible to raise the solution $\mathrm{pH}$ by using alternative reagents such as plant combustion ashes [40,103]. The experiments conducted by Huang et al. [48] stated the possibility of using plant ash as the alkali reactant obtaining that, under optimal conditions, $>96 \%$ of phosphate was recovered from swine wastewater. Wang et al. [107] coupled the use of plant ash, for $\mathrm{pH}$ setting, and magnesium pellet, as $\mathrm{Mg}^{2+}$ sources, to remove and recover the phosphorus content from livestock wastewater. With the addition of plant ash and magnesium metal of 11.66 and $3.33 \mathrm{~g} / \mathrm{L}$, respectively, the $\mathrm{PO}_{4}{ }^{3-}$ abatement was $97.69 \%$ in $60 \mathrm{~min}$ [107]. The $\mathrm{pH}$ increase can be also achieved through the wastewater aeration. In this way, in fact, the $\mathrm{CO}_{2}$ is stripped from the aqueous solution which, by varying the carbonate balance of the wastewater, results in the $\mathrm{pH}$ growth. Using $\mathrm{CO}_{2}$ degasification technique, Korchef et al. [21] obtained an efficient phosphorus recovery from synthetic wastewater. A study conducted by Fattah et al. [23] at the Lulu Wastewater Treatment Plant (Richmond, $\mathrm{BC}$ ), using a struvite crystallizer and $\mathrm{CO}_{2}$ cascade stripper, reached a $\mathrm{P}$ abatement of $90 \%$, saving $86 \%$ of caustic soda usage. Nevertheless, the efficiency of this technology depends on different parameters, i.e., the influent characteristics, temperature, aeration flowrate, etc. The results of the experiments conducted by Siciliano et al. [44] showed that the $\mathrm{CO}_{2}$ degasification technology has 
low effectiveness in the ammonium removal from high concentrated wastewater. In fact, the addition of acidic reactants of phosphorus and magnesium, required to compensate the ammonium surplus, causes a $\mathrm{pH}$ drop that cannot be balanced by air insufflation. These results agree with the statements of Saidou et al. [22] who did not detect struvite formation when aeration was applied in the treatment of synthetic solutions with a $\mathrm{pH}$ lower than 6.5. Other studies highlight the application of processes involving the combination of aeration and the use of alkaline reagents to increase the $\mathrm{pH}$ value [99].

\subsubsection{Struvite Reuse as a Reactant}

As an alternative to the use of unconventional reagents, the recycling of struvite decomposition products could be a suitable option to limit the consumption of reactants and the treatment costs in the removal of ammonium. Indeed, during struvite decomposition $\mathrm{NH}_{4}{ }^{+}$ions are released, and the residues can be used as phosphorus and magnesium source for the treatment of raw wastewater. Different decomposition techniques including struvite pyrogenation, distillation, acidolysis, chlorination, and electrolysis were developed $[4,17,104,105,129,130]$. The pyrogenation in alkali solutions has largely demonstrated its efficiency in ammonium release. The pyrogenation of MAP in $\mathrm{NaOH}$ solutions takes place according to the following reaction [104]:

$$
\mathrm{MgNH}_{4} \mathrm{PO}_{4} \cdot 6 \mathrm{H}_{2} \mathrm{O}(\mathrm{s})+\mathrm{NaOHMgNaPO}_{4}(\mathrm{~s})+\mathrm{NH}_{3}(\mathrm{~g})+7 \mathrm{H}_{2} \mathrm{O}
$$

He et al. [17] found an ammonium-release higher than $96 \%$ when struvite was pyrolyzed with an $\mathrm{OH}^{-}: \mathrm{NH}_{4}{ }^{+}$molar ratio equal to 1:1, a temperature of $90^{\circ} \mathrm{C}$, and a heating time of $2 \mathrm{~h}$. Zhang et al. [131] observed that the optimal conditions for pyrolysate production from struvite of coking wastewater were: $\mathrm{OH}^{-}: \mathrm{NH}_{4}{ }^{+}=1: 1$, heating temperature of $110^{\circ} \mathrm{C}$, and heating time of $3 \mathrm{~h}$. With the same reaction time and temperature, in a very recent work, it was confirmed that the best molar ratio of $\mathrm{NaOH}$ to $\mathrm{NH}_{4}{ }^{+}$was 1:1 for the pyrolization of struvite from composting leachate [132]. Comparable findings were reported by $\mathrm{Yu}$ et al. [133]. Türker et al. [134] stated that distillation combined with $\mathrm{NaOH}$ addition at $\mathrm{OH}^{-}: \mathrm{NH}_{4}{ }^{+}=1: 1$ induced the complete $\mathrm{NH}_{3}$ stripping in half-an-hour. The amorphous magnesium sodium phosphate $\left(\mathrm{MgNaPO}_{4}\right)$, produced from reaction 3, makes it possible for the $\mathrm{NH}_{4}{ }^{+}$to replace $\mathrm{Na}^{+}$in a basic solution, forming again $\mathrm{MgNH}_{4} \mathrm{PO}_{4} \cdot 6 \mathrm{H}_{2} \mathrm{O}$. Therefore, the struvite pyrolysate can be used to remove and recover the ammonium amount from wastewater. Successful $\mathrm{NH}_{4}{ }^{+}$abatements were obtained by exploiting the MAP decomposition residues as the unique source of phosphate and magnesium [17]. The $\mathrm{NH}_{4}{ }^{+}$abatement decreased progressively with the increase of struvite reuse cycles, and in the sixth cycle, $\mathrm{NH}_{4}{ }^{+}$removals of $84 \%$ and $62 \%$ were obtained for synthetic wastewater and landfill leachate, respectively [17]. In a five-cycle treatment of anaerobic digester effluents, $\mathrm{NH}_{4}{ }^{+}$recovery was initially $92 \%$ and then it gradually decreased to $77 \%$ in the fifth stage [134]. The authors argued that the $\mathrm{NH}_{4}{ }^{+}$abatement decreased as a fraction of recycled struvite residues remained in the supernatant during each cycle by reducing, in this way, the molar ratio required for the complete ammonium abatement. Moreover, during the subsequent treatments, the recycled magnesium phosphate became less active because the $\mathrm{Mg}_{3}\left(\mathrm{PO}_{4}\right)_{2}$ or $\mathrm{Mg}_{4} \mathrm{P}_{2} \mathrm{O}_{7}$ content increased [134]. The $\mathrm{NH}_{4}{ }^{+}$removal efficiency did not decrease, and stably remained around $90 \%$, if the pyrolysate was supplemented with soluble salts of magnesium and phosphorus during the treatment cycles [134].

The main disadvantage of pyrogenation is the high temperatures required $\left(\geq 90^{\circ} \mathrm{C}\right)$ to obtain the struvite decomposition [17]. Huang et al. [128] proposed a process based on the air stripping technique which was able to reduce the decomposition temperature and stop the formation of less active compounds $\left(\mathrm{Mg}_{2} \mathrm{P}_{2} \mathrm{O}_{7}\right)$. The authors found that the gas/liquid ratio of 3600, the temperature of $60{ }^{\circ} \mathrm{C}$, and the $\mathrm{OH}^{-}: \mathrm{NH}_{4}{ }^{+}$molar ratio of 2:1 were the optimal operating conditions for struvite decomposition, reaching an ammonium release higher than 92\% [128]. The $\mathrm{NH}_{4}{ }^{+}$removal from synthetic wastewater was stably higher than $80 \%$ by reusing the MAP decomposition products six times. In a continuous process, approximately $91 \% \mathrm{NH}_{4}{ }^{+}$and $97 \% \mathrm{PO}_{4}{ }^{3-}$ was removed and recovered 
from swine wastewater with the supplementation of bittern [128]. Anyhow, the decomposition of struvite in basic environment could cause the dispersion of $\mathrm{NH}_{3}$ in the atmosphere, making the process hardly applicable in field conditions [129].

Struvite decomposition in acidic solutions can be effectively applied at moderate operating temperature and it avoids the dispersion of ammonia gas [129]. In fact, in adequate acidic conditions, MAP is transformed in hydrated magnesium phosphates (newberyite) with the release of $\mathrm{NH}_{4}{ }^{+}$in the solution, according to the following reaction:

$$
\mathrm{MgNH}_{4} \mathrm{PO}_{4} \cdot 6 \mathrm{H}_{2} \mathrm{O}(\mathrm{s})+\mathrm{H}^{+} \rightarrow \mathrm{MgHPO}_{4} \cdot 3 \mathrm{H}_{2} \mathrm{O}(\mathrm{s})+\mathrm{NH}_{4}^{+}+3 \mathrm{H}_{2} \mathrm{O}
$$

The ammonium ions remain in the acidic solution and could be potentially reused as a fertilizer source $[4,129]$. The newberyite resulting from reaction 4 can react in a basic environment with $\mathrm{NH}_{4}{ }^{+}$ ions forming again $\mathrm{MgNH}_{4} \mathrm{PO}_{4} \cdot 6 \mathrm{H}_{2} \mathrm{O}$. Zhang et al. [129] found that ammonium was efficiently released from MAP in a $\mathrm{HCl}$ solution at $\mathrm{pH} 5.0$ and temperature $60^{\circ} \mathrm{C}$. With a dose ratio of $\mathrm{MgHPO}_{4} \cdot 3 \mathrm{H}_{2} \mathrm{O}$ to $\mathrm{NH}_{4}{ }^{+}$of 2, the MAP precipitates were repeatedly used five times reaching ammonium removal higher than 98\% [129]. Siciliano et al. [4] tested various organic and inorganic acids such as $\mathrm{H}_{2} \mathrm{SO}_{4}$ $(95 \%), \mathrm{HCl}(32 \%), \mathrm{HNO}_{3}(60 \%)$, and $\mathrm{CH}_{3} \mathrm{COOH}(80 \%)$ and, at the same time, the effects of $\mathrm{pH}$ and temperature were analyzed. The detected results demonstrated the high effectiveness of hydrochloridric and acetic acids, which permitted a high and selective release of ammonium at $\mathrm{T}=50^{\circ} \mathrm{C}$ and $\mathrm{pH}=5.5$. The multiple recycling of struvite decomposition products, combined with the addition of a low quantities of $\mathrm{PO}_{4}{ }^{3-}$ and $\mathrm{Mg}^{2+}$ at molar ratios of $\mathrm{N}: \mathrm{Mg}: \mathrm{P}=1: 0.05: 0.05$, permitted steady ammonium abatements of about $82 \%$.

Huang et al. [105] investigated the chlorination process with the dosage of $\mathrm{NaClO}$ to the struvite produced from swine wastewater. In this treatment, the overall reactions in the system can be expressed as follows [105]:

$$
\begin{gathered}
\mathrm{ClO}^{-}+\mathrm{H}^{+} \rightarrow \mathrm{HClO} \\
\mathrm{MgNH}_{4} \mathrm{PO}_{4} \cdot 6 \mathrm{H}_{2} \mathrm{O}(\mathrm{s})+\mathrm{H}^{+} \rightarrow \mathrm{MgHPO}_{4} \cdot 3 \mathrm{H}_{2} \mathrm{O}(\mathrm{s})+\mathrm{NH}_{4}^{+}+3 \mathrm{H}_{2} \mathrm{O} \\
2 \mathrm{NH}_{4}^{+}+3 \mathrm{HClO} \rightarrow \mathrm{N}_{2}+3 \mathrm{H}_{2} \mathrm{O}+5 \mathrm{H}^{+}+3 \mathrm{Cl}^{-}
\end{gathered}
$$

As the chlorination reactions proceed, the amounts of $\mathrm{Mg}^{2+}$ and $\mathrm{HPO}_{4}{ }^{2-}$ rapidly increase and, in oversaturation conditions, they may form insoluble $\mathrm{MgHPO}_{4}{ }_{3} \mathrm{H}_{2} \mathrm{O}$ and $\mathrm{Mg}_{3}\left(\mathrm{PO}_{4}\right)_{2}$ [105]. The study of Huang et al. [104] demonstrated that the struvite decomposition efficiency is affected by the $\mathrm{pH}$ and $\mathrm{Cl} / \mathrm{N}$ ratio obtaining the better performance at $\mathrm{pH} 6$ and $\mathrm{Cl} / \mathrm{N}=8.5$. The multiple recycling of MAP decomposition products proved that the ammonium removal did not decrease as the number of reuses increased [105]. According to the authors, this may be attributable to the fact that the amounts of active $\mathrm{Mg}^{2+}$ and $\mathrm{PO}_{4}{ }^{3-}$ remained unchanged during the multiple-reuses. In this treatment, however, the ammonium amount is not recovered but, instead, it is oxidized to $\mathrm{N}_{2}$.

Liu et al. [135] used electrolysis, supported by the addition of $\mathrm{NaCl}$ as an electrolyte, to induce the struvite decomposition. With the addition of $\mathrm{NaCl}$, chlorine forms at the anode and it is then transformed to $\mathrm{HCLO}$ and $\mathrm{CLO}^{-}$in the electrolytic reactor. Therefore, the overall reactions occurring in such a system are similar to those of the chlorination process. Optimum conditions for the electric voltage, $\mathrm{NaCl}$, reaction time, and initial struvite amount of $7 \mathrm{~V}, 0.06 \%, 1.5 \mathrm{~h}$, and $1.25 \mathrm{~g} / \mathrm{L}$ were found by the authors [135]. The use of dissolved struvite allowed abatements of phosphorus and ammonium from swine wastewater up to $79 \%$ and $53 \%$, respectively [135].

\section{Reactors Configurations}

\subsection{Stirred Tank Reactors-STR}

Stirred tank reactors (STR) represent the most used reactors in laboratory studies $[28,53,55-57,59-62,136,137]$. From a structural point of view, they are very simple units 
equipped with a mixing system that allows for the homogenization of the wastewater with the reactants, as well as auxiliary devices for the introduction of reagents and wastewater, the extraction of precipitate and of surnatant, and for the control of the operating parameters [28,56,58].

The mixing condition inside the reactor represents a fundamental aspect because it affects the struvite formation [57]. An effective mixing promotes the crystals nucleation and growth by improving the mass transfer of ions from the solution to the solid phase. Liu et al. [66], in a study conducted on synthetic and real urine samples, reported that by increasing the mixing energy from $160 \mathrm{rpm}$ to $240 \mathrm{rpm}$, the precipitation efficiency of struvite crystals increased by $33 \%$. The experiments conducted by Ohlinger et al. [138] showed that the struvite crystals morphology was more dendritic in the reactor's areas affected by low turbulence, while the crystals had more regular shapes in areas with greater turbulence. In effect, a too low stirring speed favors the formation of fouling on the blades of the mixer producing a reduction of the stirring efficiency and, consequently, a reduction of the quality of the struvite crystals [28]. Furthermore, insufficient stirring energy increases locally the oversaturation in the solution and, therefore, promotes the local nucleation of new struvite crystals without promoting their growth. Consequently, the crystals growth rate increases with the turbulence conditions in the reactor [12]. However, the improvements on crystals growth and morphology disappear beyond a certain mixing speed [66]. In effect, limited growth of struvite crystals was observed with stirring speed greater than $500 \mathrm{rpm}[57,95]$.

Generally, completely mixed reactors can operate continuously or in batch mode. A batch reactor works according to a series of phases and the struvite production and precipitation occur in the same unit. On the contrary, in a continuous reactor only the struvite formation takes place, while the precipitation phase occurs in a separate unit.

In some studies, a single unit was developed and used in which both the struvite formation and sedimentation occurred, and which operated continuously. This unit consisted of two parts. The bottom part was the reaction zone, while the top part was a settling zone designed to avoid the discharge of fine particles with the effluent $[28,56,82]$. The reaction zone operated as a perfectly mixed reactor [139]. The settling zone was equipped with a baffle to guide the flow. The effluent flowed out at the top of the settling zone over a weir. The mixer was an axial flow propeller. A second mixer was placed at the end of the axis to avoid solids deposition at the bottom flow gate. In the experimental set-up used by Aguado et al. [56], the reactor was provided with a solids trap put at the bottom part of the reaction zone. This purge system allowed the harvesting of the larger precipitate particles, while the smaller solids remained growing within the reactor [56]. The phosphorus recovery efficiency achieved with this configuration was greater than $87 \%$ in the treatment of separate urine. The average dimension of the recovered solids was between $110 \mu \mathrm{m}$ and $320 \mu \mathrm{m}$.

Kim et al. [53] developed a lab-scale airlift reactor able to operate in continuous mode and that was effectively used for struvite crystallization. The reactor worked with a hydraulic retention time of $10 \mathrm{~min}$ for the mixing zone, and $3 \mathrm{~h}$ for the entire reactor, obtaining $\mathrm{NH}_{4}{ }^{+}$and $\mathrm{PO}_{4}{ }^{3-}$ removal of $95 \%$ and $98 \%$, respectively.

As previously described, struvite precipitation can also be induced by the dissolving $\mathrm{CO}_{2}$ degasification technique. In these processes, the air bubbling through the solution is exploited to promote the $\mathrm{pH}$ increase but, at the same time, it allows to mix and homogenize the mixture in the reaction zone. Therefore, the air insufflation replaces the mechanical mixer in the stirred tank reactors. Clearly, the airflow rate notably influences the process efficiency as it affects the reaction $\mathrm{pH}$ and the mixing conditions. Phosphorus removal efficiency of about $78 \%$ was observed by Saidou et al. [22] for experiments conducted with air flowrates between 10 and $25 \mathrm{~L} \mathrm{~min}^{-1}$. For higher air flowrates, the phosphorus removal decreased [22]. The authors argued that with excessive air flowrates the liquid shear stress increased. This affected the transfer of struvite constituent ions from the liquid to the solid phase and inhibited their reaction with the crystal surface, hence limiting the particles growth. Therefore, it is not suitable to operate with too high flowrates as they would not improve the process performance and, on the other hand, would increase the operational costs. 
In general, in stirred tank reactors the control of the struvite formation process is simpler and manageable compared to the other technologies, which justifies their large utilization. In particular, STR are not affected by the problems related to the flow control, typical of fluidized bed reactors (FBR) [30] and they do not present plant complexities. Moreover, STR can be easily used both in batch and continuous mode. Furthermore, the hydraulic reaction time can be reduced to a few minutes, obtaining high process performances (Table 1). On the other hand, the high stirring velocity (Table 1), necessary to mix the solid particles, causes great energy consumptions and makes it difficult to control the dimension of MAP crystals [39]. In fact, fine struvite particles are generally produced in stirred tank reactors. These disadvantages can be only partially limited by exploiting the air insufflation.

\subsection{Fluidized Bed Reactors-FBR}

The FBR, in the classical configuration, consist of a central body with a predominantly longitudinal development in which crystals nucleation and growth take place [140]. The waste stream is, generally, introduced at the bottom together with the reagents necessary for struvite nucleation. From the top of the reactor, the liquid falls into an external clarifier from which part of the flow is recirculated to the bottom of the crystallization reactor $[65,68]$. In some configurations, the recirculation of the effluent and suspended struvite crystals is carried out directly from the top to the bottom of the reaction tank. The recirculation flowrate can vary considerably depending on the type of wastewater and on the characteristics of the reactor. Struvite crystals nucleation begins in the FBR central body, through mechanisms of interaction with the other struvite particles or with seeding inert materials that constitutes the fluidized bed [12,69].The fluidization of the particles in the reactor can be guaranteed either by an appropriate upward speed of the recirculation flow or by aeration [67,69-71]. The air insufflation, in addition to the bed fluidization, promotes the $\mathrm{pH}$ increase and, consequently, it reduces the dosage of alkaline compounds to reach the $\mathrm{pH}$ conditions suitable for struvite nucleation $[66,69,72]$.

Le Corre et al. [108] obtained phosphorus removal up to $80 \%$ in a study conducted on a batch FBR laboratory pilot plant by applying recirculation flowrate between 1.35 and $1.5 \mathrm{~L} / \mathrm{min}$, directly from the top of the reactor, and an airflow rate between 5 and $10 \mathrm{~mL} / \mathrm{min}$. However, the process showed an overproduction of small particles. The authors found a motivation in the actual negative surface charge of struvite crystals and proposed as possible solutions the coagulation of fine particles or the use of seed inert material, which could help to improve the growth step.

In this regard, Battistoni et al. [69] effectively used inert sand as a seed material to promote struvite crystallization and growth. In particular, the authors studied the auto-nucleation and crystal growth of struvite in a demonstrative reactor for the treatment of supernatant of anaerobic digester. By treating an influent flowrate up to $2 \mathrm{~m}^{3} / \mathrm{h}$, operating in metastable conditions, phosphorus removals between $69.4 \%$ and $86 \%$ were detected [69]. The minimum recycling flow rate, necessary to fluidize the bed, was $17 \mathrm{~m}^{3} / \mathrm{h}$ and it allowed the growth of rounded-shaped crystals with dimensions of about $0.7 \mathrm{~mm}[69]$.

On the other hand, Shimamura et al. [73] affirmed that in the conventional FBR, as the crystallization progresses, the particle sizes of MAP become large and it is difficult to keep them constant. The excessive growth of struvite particles could cause operational difficulties in the system. Therefore, the authors developed a two-tank type unit consisting of a main reaction tank and a sub reaction tank that allowed them to produce particles with uniform dimensions. In particular, fine particles (mean size 0.05 to $0.25 \mathrm{~mm}$ ), floating in the upper part of the main reaction tank, were transferred, at a frequency of once in three to four days, into the sub reaction tank where they grew up to about $0.3 \mathrm{~mm}$ [73]. These particles were returned totally into the main reactor where they acted as a seed material. With this operating mode, the average particle dimension in the main reactor remained stable. Dimensions of MAP granules around of $1 \mathrm{~mm}$ were maintained depending on wastewater characteristics, recirculation ratio, influent flowrate, and magnesium additions [73].

Several other studies aimed to verify different plant configurations for fluidized bed reactors. Bowers and Westerman [74] developed a FBR unit with conical walls for the treatment of swine lagoon 
liquid. The cone-shaped fluidized bed crystallizer offers significant advantages for precipitating the struvite particles because its range in upflow velocity (high velocity at the bottom, diminishing to a low velocity at the top) retains a wide range of particle sizes in a dense bed [74]. With this type of reactor orthophosphate removals up to $82 \%$ were reached in field conditions [74].

Other authors used a fluidized bed reactor made by different zones with an increasing diameter [24]. The diameter change causes turbulent eddies above each transition zone, ensuring adequate mixing conditions and helps to classify the fluidized particles by size $[27,68]$. The larger particles accumulate at the bottom and are harvested periodically. In the experiments of Bhuiyan et al. [68], phosphate removals of about $75-85 \%$ were detected with an upflow velocity of about $400-410 \mathrm{~cm} / \mathrm{min}$. The results detected by Fattah et al. [23] showed that the reactor with an increasing diameter was able to remove over $90 \%$ of phosphate at $\mathrm{pH}$ 7.5. Guadie et al. [70] designed a cone-inserted fluidized bed reactor which had three distinct parts, with the diameter that gradually increased toward the top, and cone-shape structures at an angle of $45^{\circ}$ between each part. The strategy of inserting of cones aimed at reducing unwanted particles loss at each junction. The authors found that with the same operating conditions, the reactor with cones obtained phosphorus removal yields between $93 \%$ and $98 \%$, while a reactor without cones reached lower removal yields between $78 \%$ and $81 \%$ [70].

In other studies, pilot scale reactors with a dual function, crystallization by aeration and struvite separation by settling were designed $[55,71,111,141,142]$. This type of reactor has an internal reaction zone, which consists of an aeration column for struvite formation, and an external settling zone for precipitate separation. Such a configuration can be easily created with only minor modifications to an existing settling tank in a wastewater treatment plant [141]. In the experiments conducted by Liu et al. [143], MAP formation was directly proportional to the aeration rate and reached a plateau at a specific flowrate of around $0.73 \mathrm{~L} /(\mathrm{L} \cdot \mathrm{min})$, with a phosphorus removal of about $92.5 \%$.

Some authors included an internal recycle of precipitate through air lift [142]. In the internal recycle seeding reactor (IRSR), seeds are lifted constantly by air from the settling zone to the reaction zone to contact with wastewater to form new struvite particles. The crystals concentration can be controlled by adjusting the circulation flowrate and the amount of solids at the bottom. This type-unit, with respect to a non-seeded reactor, permitted to increase the phosphorus recovery by $19 \%$ in the case of low $\mathrm{P}$ concentrations in wastewater, but showed comparable efficiencies in the case of high $\mathrm{P}$ influent concentrations [142].

The fluidized bed reactors have the main advantages in the rapid growth of struvite crystals [12]. Furthermore, in FBR the dimensions of MAP particles increase over time and several modalities (use of seed inert material, use of metallic meshes, use of internal seeds recycle, etc.) can be exploited to limit the fine particles production [39]. In effect, in FBR large crystals were obtained (Table 2). However, the fluidized reactors are characterized by a management complexity higher than stirred tank reactors. This is attributable to the difficulty in controlling the flows for the bed fluidization and for the eventual recycle of fine produced particles. Furthermore, the high flowrates cause, in general, high energy consumption [12,70]. In addition, the fluidization of solids in the reactor produces the erosion of internal walls and devices [39]. Therefore, a frequent maintenance may be required which increases the process expense [39].

\subsection{Bioelectrochemical Systems-BES}

Bioelectrochemical systems (BES) represent promising technologies for recovering energy, biofuels, or chemicals from wastewater treatment. BES utilize living microorganisms to drive oxidation and reduction reactions at solid electrodes [144]. With respect to conventional fuel cells, BES operate in relatively mild conditions and do not exploit costly precious metals as catalysts [145]. BES can be divided into two main categories: Microbial fuel cells (MFC) and microbial electrolysis cells (MEC). The first one, thanks to the action of microorganisms, produces electricity, while the second one exploits electricity to produce biofuels [144]. In addition to the conventional applications, BES could play a role in the recovery of nutrients in the form of struvite in the wastewater treatment plants [146-150]. 


\subsubsection{Microbial Fuel Cells-MFC}

MFC are bio-electrochemical systems that generate electricity by reproducing the natural bacterial interactions in which microorganisms catalyze organic compounds such as glucose, acetate, butyrate, or wastewater [151,152]. By oxidizing the organic substance, the electrons from the anode migrate, through an electric circuit, to the cathode to be transferred to an electron acceptor such as oxygen [153]. Shewanella putrefaciens [154], Aeromonas hydrophila [155], Escherichia coli [156], and other microorganisms, are used for the catalytic activities through which an electromotive force is generating.

Fischer et al. [156] proved that MFC could be applied for phosphate recovery from digestate of sewage sludge. In this application, a MFC system was exploited exclusively to release orthophosphate from iron phosphate contained in the digestate. A successive addition of $\mathrm{Mg}^{2+}$ and $\mathrm{NH}_{4}{ }^{+}$, as well as $\mathrm{pH}$ setting, were executed outside MFC for phosphorus recovery as struvite crystals [156]. You et al. [148] developed a three-stage MFC/struvite extraction system to maximize urine utilization in terms of electricity generation and struvite recovery. This system consists of a stirred reactor for struvite precipitation put between two MFC units. The authors observed that placing MFC before the struvite precipitation process helped struvite collection by accelerating urea hydrolysis, and furthermore, removing struvite from urine before the MFC helped minimize system blockages without hindering MFC performance. With this system $82 \%$ of phosphate was removed [148].

Ichihashi and Hirooka [157] found that phosphorus can be removed and recovered directly through MFC because of the struvite crystals deposition on the surface of the liquid side of the cathodes. Indeed, a local pH growth occurs near the cathode, where water is being consumed and hydroxide is generated as a byproduct [157]. This $\mathrm{pH}$ increase, in presence of sufficient amounts of $\mathrm{Mg}^{2+}$ and $\mathrm{NH}_{4}{ }^{+}$, creates favorable conditions for struvite crystallization. In a study conducted in a single chamber MFC reactor, phosphorus recovery efficiencies, in the form of struvite, of up to $40 \%$ were observed [58,157-159]. Tao et al. [160] compared the removal efficiencies of phosphorus and ammonium in a single-chamber MFC reactor and a two-chamber system. The work proved that the two systems can both efficiently remove phosphorus with efficiencies close to 90\% [160]. However, phosphorus was removed by the mutual effect of chemical precipitation and microbial absorption. Exclusively on the cathode of the single chamber, crystals with prismatic morphology typical of struvite were observed [160]. Santoro et al. [159] treated human urine in a single chamber MFC reactor demonstrating the possibility of phosphorus recovery in the form of struvite and hydroxyapatite. Furthermore, the high concentrations of ammonium generated by the hydrolysis of urea are potentially recoverable in the form of struvite by adding $\mathrm{Mg}^{2+}$ and $\mathrm{PO}_{4}{ }^{3-}$ based reagents until reaching the equimolar conditions [148,159].

Hirooka and Ichihashi [150] evaluated the effect of $\mathrm{NH}_{4}{ }^{+}$and $\mathrm{Mg}^{2+}$ additions on the precipitation of phosphorus in artificial wastewater by an air-cathode single-chamber microbial fuel cell. The experimental results proved that when both $\mathrm{NH}_{4}{ }^{+}$and $\mathrm{Mg}^{2+}$ were dosed the phosphorus was removed through struvite precipitation at the cathode.

However, the fouling on the cathode, reducing the electrical performance of the cell, is one of the main problems related to the MFC operations. Indeed, the accumulation of solids blocks mass transfer near the cathode, therefore, to restore the system efficiency, the deposited solids must be frequently removed [150,159].

\subsubsection{Microbial Electrolysis Cells-MEC}

In a Microbial Electrolysis Cells (MEC) the electrons migrate from the anode, where the organic substrate is oxidized, to the cathode where, through the addition of electricity from the outside and in the presence of a suitable catalyst, it is possible to obtain valuable products such as $\mathrm{H}_{2}, \mathrm{CH}_{4}$, and chemicals as struvite $[144,146,147,161]$.

Cusick and Logan [146] investigated the phosphorus recovery as struvite in a single chamber MEC unit. The MEC cathodes were either stainless steel 304 mesh or flat plates. Phosphorus removal was between $20 \%$ and $40 \%$, with higher removal reached with mesh cathodes than using flat plates. Cathode 
accumulated solid were verified as struvite crystals. In a subsequent study by Cusick et al. [147], a two-chamber MEC reactor with a fluidized bed cathode chamber was developed to ameliorate phosphorus abatement and limit cathode scaling. In this system, the particles scour the cathode and help to reduce scale accumulation.

The authors observed phosphate reductions in digestate supernatant between $70 \%$ and $85 \%$, with an energy consumption of $0.2-0.3 \mathrm{Wh} / \mathrm{L}$, notably less than that needed in other methods for struvite formation [147]. The collected solids showed an equimolar composition of $\mathrm{Mg}$ and $\mathrm{P}$ supporting phosphorus removal through struvite formation [147].

In the study conducted by Almatouq and Babatunde [161] on synthetic wastewater with a chemical oxygen demand (COD) of $500 \mathrm{mg} / \mathrm{L}$, using a double-chamber electrolytic microbial cell, a phosphorus removal of $95 \%$, in the form of struvite, was found. Furthermore, $\mathrm{H}_{2}$ was produced with a maximum production rate of $0.28 \mathrm{~m}^{3} \mathrm{H}_{2} / \mathrm{m}^{3} \mathrm{~d}$, by applying a voltage of $1.1 \mathrm{~V}$. The produced hydrogen could be used as an energy source to reduce the operating costs of struvite production [147,162]. This study highlighted the problem of fouling due to the accumulation of struvite on the cathode which causes a reduction in the efficiency of the MEC reactors. In effect, although MFC and MEC are promising technologies, the actual applicability at an industrial level still seems very far away, therefore, further studies are needed for their development.

\subsection{Ion Exchange Technologies}

Adsorption/ion exchange are promising methods for nutrients removal as they are simple, economical, and result in less sludge production [163]. Ion exchange process is suitable for reducing nutrient amounts provided that the ion exchange resins are selective, low cost, and effectively regenerable and reusable [164]. Ion exchange resins are, typically, used as filter media in filter-based systems and after a period of utilization they become exhausted, causing a deterioration in the removal efficiency. The exhausted resins can be regenerated using proper regenerating chemicals or a mixture of them [164]. The nutrient removed during the regeneration of resin can be subsequently recovered by precipitation as struvite [164]. In particular, the REM NUT process is based on two commercial exchangers, a natural zeolite and a strong base anion resin removing $\mathrm{NH}_{4}{ }^{+}, \mathrm{K}^{+}$, and $\mathrm{PO}_{4}{ }^{3-}$, respectively, from biologically oxidized urban wastewater. Nutrients are then recovered by precipitation from the exchangers spent regeneration effluents in the form of $\mathrm{NH}_{4}{ }^{+}$and/or $\mathrm{K}^{+}$struvite [163]. According to Petruzzelli et al. [163], one of the main limitations of this process is the low availability of effective $\mathrm{PO}_{4}{ }^{3-}$ selective sorbents, which prevents its application on a full scale. The authors investigated a "P-driven" version of the REM NUT ${ }^{\circledR}$ scheme using a $\mathrm{PO}_{4}{ }^{3-}$ selective sorbent developed at Lehigh University, PA, USA [163]. P removals stably higher than $80 \%$ were reached in subsequent cycle runs [163]. Other types of resins were tested for phosphorus recovery [164]. Nur et al. [164] used the Dowex 21K XLT resin for P adsorption from a membrane bioreactor effluent. The resin showed a maximum $\mathrm{PO}_{4}{ }^{3-}$ absorbing capacity of $38.6 \mathrm{mg} / \mathrm{g}$ [164]. The adsorbed phosphate was desorbed by leaching the column with $0.1 \mathrm{M} \mathrm{NaCl}$ solution and, afterwards, it was recovered as struvite through the addition of $\mathrm{NH}_{4}{ }^{+}$and $\mathrm{Mg}^{2+}$ at the stoichiometric molar ratios and $\mathrm{pH} 9.5$ [164].

Contrary to the conventional applications in which ion exchange processes are used to catch nutrient ions from wastewater, Mijangos et al. [165,166] exploited the ion exchange isothermal supersaturation (IXISS) to recover struvite with spontaneous precipitation reactions. In the IXISS process $\mathrm{Mg}^{2+}$ is stripped from a weak cationic resin and replaced with the excess of $\mathrm{NH}_{4}{ }^{+}$in the wastewater $[165,166]$. The highly supersaturated solution, containing $\mathrm{Mg}^{2+}, \mathrm{PO}_{4}{ }^{3-}$, and the residual $\mathrm{NH}_{4}{ }^{+}$, remains stable while it is flowing alongside the fixed bed, therefore avoiding clogging problems. After leaving the column, the chemical environment destabilizes the supersaturated solution, and this promotes reagentless struvite precipitation. The authors obtained stable supersaturated MAP solutions by stripping magnesium from Lewatit CNP80 cation exchange resin in Mg-form, under batch and dynamic conditions $[165,166]$. The $\mathrm{pH}$ of MAP formation was about 8.0 and X-ray diffractograms of the produced precipitates confirmed the presence of MAP crystals [167]. Ortueta et al. [167] studied three 
different ion exchangers: Lewatit CNP80 macroporous carboxylic resin, Lewatit S100 microporous sulphonic resin, and Amberlite IRC86 macroporous sulphonic resin, for production of MAP. In the case of the carboxylic microporous resin, Amberlite IRC86, was proved the presence of struvite in the produced precipitate through XRD analysis.

However, the applicability of ion exchange processes can be notably limited by the characteristics of wastewater. Indeed, by treating wastewater with high suspended solids, such as anaerobic mud or swine waste, fouling phenomena can make the exchange columns ineffective [168]. Therefore, strong pretreatments are necessary before ion exchange processes.

\subsection{Membrane Technologies for Nutrients Recovery}

Membrane separation technologies separate the incoming wastewater stream into two fractions, the aqueous flow that passes through the membrane, called permeate, and the phase rich in solids, called retentate [169]. The membranes selectively separate the different components of the wastewater mainly based on the size and without phase transformation. Membranes can be built with organic or inorganic materials [169]. The membrane operations of interest in this area include microfiltration (MF), ultrafiltration (UF), nanofiltration (NF), reverse osmosis (RO) and forward Osmosis (FO), electrodialysis (ED) [170].

In particular, the nutrients in particulate form can be recovered by UF and NF, while the nutrients present in soluble form can be recovered by $\mathrm{RO}$ or FO.

Generally, the use of these technologies for the struvite precipitation processes aim to obtain a permeate or a retentate rich in $\mathrm{N}$ and $\mathrm{P}$ so as to be subsequently recovered by precipitation [171-175].

$\mathrm{Bu}$ et al. [172] evaluated the possibility of ammonium and phosphorus recovery in the permeate of an anaerobic membrane bioreactor (AnMBR) treating swine manure. At $\mathrm{pH} 9$ a phosphorus removal of about $70.5 \%$ was reached, obtaining struvite crystals with a purity of $98 \%$ [172].

Hakimi et al. [176] studied the struvite precipitation process on the permeate of AnMBR reactor treating abattoir effluent. In this study $82 \%$ and $66 \%$ removal of phosphate and ammonium, respectively, were reached at $\mathrm{pH}$ 9.5. Kumar and Pal [173] applied a membrane-integrated hybrid system for the removal and recovery of ammonium from wastewater of a coke-making plant. After a nanofiltration process the permeate side had high concentrations of $\mathrm{NH}_{4}{ }^{+}$in the uncontaminated form, as impurities were rejected. Ammonium was recovered through MAP precipitation in a separate STR reactor by dosing external sources of $\mathrm{Mg}^{2+}$ and $\mathrm{PO}_{4}{ }^{3-}$. Over $97 \%$ of ammoniacal nitrogen precipitated out as struvite at stoichiometric molar ratios and $\mathrm{pH} 9$ [173].

Other studies evaluated the possibility of recovering phosphorus and nitrogen via forward osmosis [175]. In this technology water passes from a solution with lower osmotic pressure into a solution with higher osmotic pressure that is known as the draw solution (DS) [171]. The process can concentrate $\mathrm{PO}_{4}{ }^{3-}, \mathrm{Mg}^{2+}$, and $\mathrm{NH}_{4}{ }^{+}$in the feed side to allow MAP recovery [172]. The forward osmosis has several advantages such as high pollutants rejection and lower fouling tendency in comparison to conventional pressure-driven membrane processes [171]. Studies were conducted testing different types of draw solute for the nutrients concentration. Zhang et al. [177] and Xue et al. [178] exploited seawater brine as a draw solution for mining nutrients from urban wastewater and urine. Xie et al. [179] used $\mathrm{MgCl}_{2}$ as a draw solution for nutrients removal from anaerobically digested sludge centrate. Volpin et al. [175] used a commercial fertilizer blend as DS to concentrate real diluted urine. During the concentration, the urea in the urine was recovered because it diffused to the fertilizer. The mixture of concentrated $\mathrm{PO}_{4}{ }^{3-}$, reverse $\mathrm{Mg}^{2+}$ flux from the DS, and the magnesium ions present in the flushing water permitted to recover about $93 \%$ phosphate, in the form of MAP, in a separate crystallization unit [175]. Pramanik et al. [171] studied the effects of different draw solutions $\left(\mathrm{MgCl}_{2}, \mathrm{EDTA}-2 \mathrm{Na}\right.$, and $\mathrm{NaCl}$ ) on the $\mathrm{FO}$ performance for the treatment of digested dairy manure, followed by phosphorus recovery through struvite precipitation. $\mathrm{MgCl}_{2}$ gave the best results because the reverse flux of $\mathrm{Mg}^{2+}$ to the concentrated inlet flow provided favorable conditions for struvite crystallization. 
Despite the encouraging results in experimental works, the membrane technologies are hardly applicable in field conditions due to some unfavorable aspects. The main disadvantages of using membrane technologies include the high energy costs and the fouling phenomena.

\section{Full-Scale Struvite Recovery Technologies}

In addition to the numberless applications at laboratory and pilot scale plants, currently, due to its profitable aspects, the struvite recovery processes are applied at industrial scale for the treatment of municipal and industrial wastewater and agro-industrial waste [19]. The most used industrial-scale technologies include:

- $\quad$ OSTARA $\left(\right.$ Pearl $\left.^{\circledR}\right)$. Ostara technology uses a FBR for struvite crystals recovery consisting of three zones with an increasing diameter from the bottom to the top. In the lower area, there is reagents feeding and recovery of struvite crystals; in the central one the nucleation and growth of the crystals take place; while in the upper part, the discharge of the treated wastewater occurs. The effluent is recirculated with a flow rate of about 20 times the inlet flow [180]. $\mathrm{MgCl}_{2}$ is added to guarantee the molar ratio Mg:N:P equal to 1:1:1, while $\mathrm{NaOH}$ is added as an alkaline reagent [19]. This technology has been developed since 2005 by the University of British Columbia. Currently, 22 plants that use this technology are installed all over the world, most of which are located in the USA and Canada. Ostara technology allows up to $22 \%$ of total phosphorus to be recovered in an urban sidestream wastewater treatment plant, and up to $95 \%$ of phosphorus and $15 \%$ of ammonia nitrogen in the treatment of digestion supernatants [181]. Furthermore, the process allows daily productions of about $500 \mathrm{~kg} / \mathrm{d}$ of struvite particles with sizes between 1.5 and $4.5 \mathrm{~mm}$ [20].

- $\quad$ SEABORNE. The Seaborne process was developed in 2006 in Germany and it involves nutrients recovery from digested sludge pretreated with sulfuric acid [181]. The technology consists of a first acidification phase with $\mathrm{H}_{2} \mathrm{SO}_{4}$ to extract nutrients and metals. The remaining solid phase is incinerated while the liquid phase undergoes a process for the recovery of the heavy metals by gas-liquid precipitation using $\mathrm{H}_{2} \mathrm{~S}$-rich biogas [181]. Subsequently, nutrients recovery as struvite takes place in a completely mixed reactor after the addition of $\mathrm{Mg}(\mathrm{OH})_{2}$, as a magnesium source, and $\mathrm{NaOH}$ to reach the $\mathrm{pH}$ 9. Finally, the residual dissolved ammonium is recovered through a scrubber in the form of ammonium sulfate $[19,20]$.

- $\quad$ PHOSPAQ ${ }^{\mathrm{TM}}$. This process, developed in Holland, aims at the removal both of phosphorus and ammonium present in the wastewater. The process takes place in a completely mixed aerated reactor to obtain the simultaneous degradation of COD and nutrients recovery in the form of struvite. Aeration permits the biological COD oxidation and, at the same time, the $\mathrm{CO}_{2}$ stripping which favors the establishment of $\mathrm{pH}$ values around to 8.2, suitable for the struvite precipitation [19]. $\mathrm{MgO}$ is dosed as a source of $\mathrm{Mg}^{2+}$ to reach the stoichiometric $\mathrm{N}: \mathrm{Mg}: \mathrm{P}$ molar ratios. With this technology it is possible to produce MAP particles with dimensions of about $0.7 \mathrm{~mm}[19,20]$. Phosphorus removals between $75 \%$ and $81 \%$ were obtained in an industrial-scale application conducted on potato processing wastewater.

- $\quad$ ANPHOS $^{\circledR}$. This technology for phosphorus recovery was developed in the Netherlands and operates in batch conditions. In particular, in a first aerated reactor the waste alkalinization takes place by $\mathrm{CO}_{2}$ stripping, while in a second reactor, $\mathrm{Mg}(\mathrm{OH})_{2}$ is introduced as a source of $\mathrm{Mg}^{2+}$ to promote the MAP formation. This process can recover $80-90 \%$ of the phosphorus contained in the influent. Once dried, the produced struvite can be directly used as a fertilizer [20]. With this treatment, a reduction in the influent COD also occurs, which leads to a lower oxygen consumption in the subsequent treatments [20].

- PHOSNIX. The process involves the phosphorus recovery as struvite from supernatants of digested sludge in a fluidized bed reactor [67]. This process was developed by the Japanese company Unitika Ltd. Environmental and Engineering Division. $\mathrm{Mg}(\mathrm{OH})_{2}$ is dosed as a source of magnesium, until the molar ratio of Mg:P of 1:1 is reached to allow struvite crystals nucleation and 
growth. $\mathrm{pH}$ values between 8.2 and 8.8 are guaranteed by an aeration system and the addition of $\mathrm{NaOH}$, which also promote the ammonium stripping. The process allows recovering struvite crystals directly usable as fertilizers between $0.5-1 \mathrm{~mm}$ in size [67].

- $\quad$ NuReSYS. The NuReSYS (Nutrients Recovery System) process was developed in Belgium for struvite recovery from digested sludges and dewatering effluents. This process allows the continuous recovery of the phosphorus using a completely mixed reactor [67]. The $\mathrm{pH}$ suitable for struvite crystallization is guaranteed by an aeration system which induces the $\mathrm{CO}_{2}$ stripping. The process can operate in two different modes. Specifically, it can be applied to favor the spontaneous precipitation of struvite, without adding magnesium, to avoid the scale formation on the sludge management equipment. The other configuration, instead, exploits the introduction of $\mathrm{Mg}(\mathrm{Cl})_{2}$, as a source of magnesium, to allow better efficiency in phosphorus removal. Phosphorus abatement about $96 \%$ and a production of struvite particles of variable sizes between 2 and $6 \mathrm{~mm}$, were obtained with NuReSYS process [126].

- $\quad$ AirPrex $^{\circledR}$. AirPrex technology was developed in Germany to solve the struvite incrustation problems downstream of the anaerobic digestion processes [182]. This technology uses two reactors for struvite precipitation and recovery from digestates before dehydration treatment. In the first reactor, the nucleation and growth of struvite crystals take place. This unit is aerated to promote the $\mathrm{pH}$ increase around 8 and to keep the struvite crystals in agitation. Two vertical partitions further promote an effective circulation. The second conical bottom reactor allows the sedimentation of struvite crystals and the discharge of the purified effluent [20].

- $\quad$ MULTIFORM $^{\mathrm{TM}}$. Multiform technology was developed in the United States for nutrients recovery from agro-industrial wastewater. The plant unit consists of a cone-shaped fluidized bed reactor that allows to remove about $80 \%$ of the phosphorus from wastewater with a struvite crystals retention time equal to three days [74]. Crystallization is favored by adding $\mathrm{Mg}(\mathrm{Cl})_{2}$, as a source of magnesium, and $\mathrm{NaOH}$ as an alkaline reagent. Although the struvite crystals are produced quickly, the crystals obtained have a low degree of purity [74].

\section{Use of Struvite as a Fertilizer}

Struvite has some characteristics very favorable for the use in agronomic applications. First of all, struvite contains essential nutrients such as nitrogen and phosphorus for plant growth [39]. Furthermore, its low solubility in environmental conditions induces a slow release of ammonium and phosphorus in the soil, which allows optimal plant growth over the time, avoiding potentially harmful overdose phenomena [183]. Finally, the struvite precipitation from waste and wastewater recovers nutrients that would be otherwise dispersed in the environment, saving environmental and economic damages [184]. Zhang et al. [183] calculated that for every $100 \mathrm{~m}^{3}$ of treated livestock wastewater, up to $1 \mathrm{~kg}$ of struvite can be recovered, allowing to avoid the dispersion of nutrients in surface water bodies.

Anyhow, the potential reuse in agronomic practices should satisfy specific legal requirements. Clearly, the recovered compounds must not contain hazardous elements able to produce environmental impacts or human health damage. The EU Fertilizing Products Regulation ((EU) 2019/1009) [185], in the case of inorganic macronutrient fertilizers, establishes threshold values for the following elements: $\mathrm{Cd}\left(60 \mathrm{mg} / \mathrm{kg}_{\text {P2O5 }}\right), \mathrm{Cr}^{6+}\left(2 \mathrm{mg} / \mathrm{kg}_{\text {dry matter }}\right), \mathrm{Hg}\left(1 \mathrm{mg} / \mathrm{kg}_{\text {dry matter }}\right)$, $\mathrm{Ni}\left(100 \mathrm{mg} / \mathrm{kg}_{\text {dry matter }}\right), \mathrm{Pb}\left(120 \mathrm{mg} / \mathrm{kg}_{\text {dry matter }}\right)$, As ( $40 \mathrm{mg} / \mathrm{kg}$ dry matter $), \mathrm{C}_{2} \mathrm{H}_{5} \mathrm{~N}_{3} \mathrm{O}_{2}(12 \mathrm{mg} / \mathrm{kg}$ dry matter $)$, $\mathrm{ClO}_{4}{ }^{-}\left(50 \mathrm{mg} / \mathrm{kg}_{\text {dry matter }}\right), \mathrm{Cu}\left(600 \mathrm{mg} / \mathrm{kg}_{\text {dry matter }}\right)$ and $\left(1500 \mathrm{mg} / \mathrm{kg}_{\text {dry matter }}\right)$. In addition to these limits, a fertilizer containing more than $1 \%$ by mass of organic carbon shall meet requirements for pathogens [185]. Similarly, the legal regulations in other countries fix limits for heavy metals and organic micropollutants $[33,111]$. Therefore, it is essential to recover a precipitate characterized by limited amounts of hazardous elements. In this regard, struvite has been shown to be characterized by a low content of heavy metals and dangerous micropollutants, such as PCBs [33,186].

Several studies were carried out to evaluate the effects on plant growth using struvite recovered from wastewater as a fertilizer $[34,41,128,186]$. Struvite was tested as a slow-release fertilizer in pot 
plants, vegetable crops, ornamental plants, turf grass, and field crops [51]. El-Diwani et al. [63] conducted a comparative study on broad bean growth rate using a commercial fertilizer and struvite recovered from the treatment of industrial wastewater. In particular, the study compared the broad bean growth in absence of fertilizers with struvite and using a mixture of pure fertilizing compounds. The struvite was dosed at a rate of $2 \%$, whereas, in the sample with pure compounds, nitrogen, phosphorus, and potassium were applied at a rate of 20,50 , and $40 \mathrm{mg} / \mathrm{Kg}_{\text {soil }}$ as ammonium nitrate, superphosphate, and potassium sulphate, respectively. The results of plant growth tests showed that the application of struvite increased the fresh and dry weight of broad bean plants at different stages of growth.

$\mathrm{Li}$ and Zhao [51], to assess the fertilizing power of the struvite, recovered from landfill leachate, executed a set of pot tests using four species of vegetables including Chinese flowering cabbage, Chinese chard, water spinach, and water convolvulus. Each plant was growing without added fertilizer, with struvite supplementation, and with the feeding of a model fertilizer. The germination and growth of the vegetables in the pots with struvite showed notably higher rates compared to those in control tests [51]. The experiments also proved that, due to its poor solubility in water, the struvite overdosing did not cause any problems. Furthermore, the authors observed that the MAP utilization did not result in more heavy metals in the vegetables than those from control and model fertilizer [51]. Yetilmezsoy and Zengin [110] also studied the potential use of struvite, recovered from UASB treated poultry manure wastewater, through a series of tests with fast-growing plants such as portulaca (Portulaca oleracea), garden cress (Lepidum sativum), and grass (Lolium perenne). In particular, a comparison was made using garden soil as control; garden soil with addition of struvite; sand with addition of $\mathrm{KCl}$ as control; sand with addition of $\mathrm{KCl}$ and MAP precipitate.

The experiments showed that the plants that were treated with struvite grew much faster than the garden soils and the samples with only $\mathrm{KCl}$. Moreover, the application of struvite notably increased both fresh and dry weights of the plants up to $257 \%$ and $402 \%$, respectively [110].

Liu et al. [130] conducted a study using MAP recovered from swine waste as a slow-release fertilizer for corn growth. In this study, plant growth was evaluated on an unfertilized soil (control), on a soil fertilized with struvite, and on a soil fertilized with a generic chemical fertilizer, consisting of a superphosphate $\left(20 \%\right.$ of $\left.\mathrm{P}_{2} \mathrm{O}_{5}\right)$ and urea $(46 \%$ of $\mathrm{N})$ [130]. The results showed that struvite can be successfully applied to the cultivation of corn in pots as the plants' heights and circumferences, as well as the nutritional components, were similar in plants fertilized with MAP and with generic chemical fertilizers [130].

Ryu et al. [186] compared the fertilizing power of struvite recovered from a semiconductor wastewater treatment plant with those of complex commercial fertilizers and organic compost for Chinese cabbage cultivation. The tests showed different growth rates in relation to the type of used fertilizer. In particular, the tests carried out with struvite showed the second-best growth rate, second only to the samples treated with the complex fertilizer [186]. The best performances of the complex fertilizer have been identified in the greater supply of potassium $(\mathrm{K})$. The lowest accumulation of $\mathrm{Cu}$ and no detection of $\mathrm{Cd}, \mathrm{As}, \mathrm{Pb}$, and $\mathrm{Ni}$ was observed in the struvite-treated samples. Overall, a dosage of $1.6 \mathrm{~g}_{\text {struvite }} / \mathrm{kg}_{\text {soil }}$ was identified to effectively grow Chinese cabbage [186].

Uysal et al. [34] conducted a study on tomato and corn plant growth using struvite recovered from the anaerobic effluent of the baking yeast industry. Four different sets of experiments were performed to evaluate struvite effect on crops: a set without the use of any fertilizer, a set with $\mathrm{NH}_{4} \mathrm{NO}_{3}$, a set with the addition of fertilizer based on $\mathrm{NH}_{4} \mathrm{NO}_{3}$ and $\mathrm{KH}_{3} \mathrm{PO}_{4}$, and finally, a set in which the recovered struvite was added with four different dosages $\left(2.85,5.71,8.58,11.42 \mathrm{~g}_{\text {struvite }} / \mathrm{kg}_{\text {soil }}\right)$ [34]. The results showed that with the minimum dosage of struvite $\left(2.85 \mathrm{~g}_{\text {struvite }} / \mathrm{kg}_{\text {soil }}\right)$ the same quantitative results were obtained as commercial fertilizer, while the best result in terms of dosage was equal to a quantity of struvite of $5.71 \mathrm{~g}_{\text {struvite }} / \mathrm{kg}_{\text {soil }}$ [34].

Siciliano [41] carried out agronomic tests to analyze the fertilizing potential of struvite precipitate recovered from the treatment of methanogenic landfill leachate. The fertilizing effects of MAP 
in cultivating Spinacia oleracea were compared with those of vegetable soil and of a commercial fertilizer [41]. The growth of vegetables in the pots with MAP was notably higher than those in the pots with only garden soil and in the pots with the fertilizer. Moreover, the struvite utilization as fertilizer did not result in an increase of metals absorption by vegetables [41].

These studies confirmed the effectiveness of MAP recovered from aqueous waste and wastewater as a slow release fertilizer. In effect, as previously discussed, struvite is produced at industrial scale and, among the different processes, the struvite products Pearl and NuReSYS are certified as fertilizers in the United States, United Kingdom, and Belgium, respectively. In addition, the struvite obtained by the Seaborne process is used locally.

\section{Economic Considerations}

The actual applicability of struvite precipitation for the removal and recovery of nutrients from waste and wastewater process is, obviously, strictly related to economic evaluations. For this analysis, the construction costs, the operational costs, and the potential benefits detectable by the struvite reusing and selling should be considered [86]. The struvite precipitation process generally exploits common reactors and separation units whose construction costs are quite restricted. Therefore, in the evaluation of the economic sustainability, the operational costs have a major impact which largely depend on the characteristics of wastewater subjected to the treatment. In particular, the addition of reactants, required to create the chemical conditions for struvite formation, and the consumption of energy, for the agitation systems, represents the main expense items $[69,187]$. In the literature there is a variety of processes for the recovery of struvite from wastewater. The cost of these processes cannot be well compared due to the differences in the operational conditions.

In general, the use of the air insufflation could permit a significant reduction in the overall process costs. In effect, as previously discussed, the air flux guarantees the mixing conditions and, moreover, it allows to set the $\mathrm{pH}$ to the required values for struvite precipitation, saving the consumption of the alkaline reagents. However, this approach is effective only when the treatment is aimed at the removal and recovery of phosphorus content.

The use of pure reagents generally results in a very expensive treatment. For this reason, the use of unconventional low-cost reactants is currently a key topic in the development of sustainable struvite precipitation processes. For the recovery of the phosphorus, the consumption of magnesium reactants can affect up to $75 \%$ of the total costs $[54,66,90,103]$. Etter et al. [116], in a study conducted on separate urine using a $500 \mathrm{~L}$ reactor with a struvite recovery efficiency of $90 \%$, estimated the treatment costs using three different magnesium sources: $\mathrm{MgSO}_{4}$, bittern, and magnesite. Assuming an average selling price of struvite of about $0.41 € / \mathrm{kg}_{\text {struvite }}$, the use of $\mathrm{MgSO}_{4}$ was found to be very expensive to generate profits, while using magnesite, the estimated gain was three times higher than that determined using bittern [116]. Clearly, such an analysis is affected by the assumed price of the struvite, of which real market value is very difficult to define. In effect, Ueno and Fujii [67] reported that it is possible to sell the struvite obtained from the sewage dewatering sludge treatment at $245 € /$ Ton.

Dockhorn [188] calculated the cost for phosphorus recovery from digested sludges assuming $\mathrm{P}$ concentrations between $50 \mathrm{mg} / \mathrm{L}$ and $800 \mathrm{mg} / \mathrm{L}$. According to the author, the expense per ton of produced struvite varies from $2800 € /$ Ton, by treating effluent with a $\mathrm{P}$ concentration of $50 \mathrm{mg} / \mathrm{L}$, to $520 € /$ Ton in the case of wastewater with a phosphorus level of $800 \mathrm{mg} / \mathrm{L}$ [188]. Moreover, it was estimated that the overhead costs can be decreased by $30 \%$ using a low-cost magnesium source.

Huang et al. [106], using $\mathrm{Mg}$ metal a $\mathrm{Mg}^{2+}$ source for P recovery from swine wastewater, estimated that the chemical costs in a continuous-flow reactor could amount at $0.25 \$ / \mathrm{kg}$ of recovered struvite or $0.21 \$ / \mathrm{m}^{3}$ of treated wastewater. The authors observed that the cost for providing the $\mathrm{Mg}^{2+}$ by the corrosion of magnesium metal was greater than that of using the $\mathrm{MgO}$, but it was in line with those of using $\mathrm{MgCl}_{2}$ and $\mathrm{MgSO}_{4}$ [106].

Gunay et al. [90] found that, in the removal of $\mathrm{NH}_{4}{ }^{+}$from landfill leachate, when magnesite was used instead of $\mathrm{MgCl}_{2}$, the contribution of magnesium cost to the total operation costs decreased from 
$40.2 \%$ to $4.4 \%$. However, when the treatment aims at the removal of ammonium, the consumption of phosphorus reagents represents the primary cost of the whole process $[1,41,44,187]$. Indeed, Di Iaconi et al. [1] calculated a cost of about $24 € / \mathrm{m}^{3}$ in the treatment of leachate using $\mathrm{MgO}$ and $\mathrm{H}_{3} \mathrm{PO}_{4}$ as magnesium and phosphorus sources. Considering the quantity of ammonium removed in the process (i.e., about $2.5 \mathrm{~kg} \mathrm{NH}_{4}{ }^{+}-\mathrm{N}$ per m${ }^{3}$ of leachate), a specific cost of $9.6 € / \mathrm{kgNH}_{4}{ }^{+}-\mathrm{N}$ removed was calculated [1]. The authors' estimations indicate that the cost of $\mathrm{H}_{3} \mathrm{PO}_{4}$ represents approximately $50 \%$ of the entire costs [1].

Huang et al. [121] conducted an economic evaluation by comparing the utilization of waste $\mathrm{H}_{3} \mathrm{PO}_{4}$ and low-cost $\mathrm{MgO}$ respect to other chemicals combinations. The overall expense for chemicals consumption was found to be $19 \$ / \mathrm{m}^{3}$ in the case of using $\mathrm{MgCl}_{2} \cdot 6 \mathrm{H}_{2} \mathrm{O}, \mathrm{Na}_{2} \mathrm{HPO}_{4} \cdot 12 \mathrm{H}_{2} \mathrm{O}$, and $\mathrm{NaOH}$. The total cost decreased to $5.99 \$ / \mathrm{m}^{3}$ when waste phosphoric acid and $\mathrm{MgO}$ were used as reactants [121].

Siciliano and De Rosa estimated a total cost of about $5.4 € / \mathrm{m}^{3}$ by using bone meal as phosphorus source, and bittern as magnesium source, in the ammonium removal from digestate [44]. Instead, the outlay resulted in about $10.2 € / \mathrm{m}^{3}$ using pure reagents $\left(\mathrm{MgCl}_{2} 6 \mathrm{H}_{2} \mathrm{O}\right.$ and $\left.\mathrm{H}_{3} \mathrm{PO}_{4}\right)$ [44]. Therefore, these results indicate that the use of bone meal and seawater bittern allows at least halving the overall chemical expense. In another study, Siciliano [41] found an overall cost of about $7.98 € / \mathrm{m}^{3}$ by using the abovementioned low-cost reagents (bone meal and bittern) for the treatment of landfill leachate. By taking into account that the recovered struvite was around $63 \mathrm{~kg} / \mathrm{m}^{3}$ of treated leachate, the production cost was $127 € /$ ton of produced struvite. This cost is about half the price of commercial fertilizers composed both of ammonium and phosphorus such as $\left(\mathrm{NH}_{4}\right)_{3} \mathrm{PO}_{4}$ [41].

Other works proved the possibility to notably reduce the operational costs for ammonium removal from high concentrated wastewater by reusing the by-products obtained from struvite decomposition, as magnesium and phosphorus source $[4,77,104]$. This approach, however, does not allow recovering and reusing the struvite as a slow release fertilizer.

\section{Conclusions}

The present review aims to assess the progress in struvite precipitation processes. The theoretical background, the operational conditions, the type of reactants, the reactors configurations, and the industrial applications are examined. Great attention was placed on the identification of unconventional low-cost reagents exploitable for struvite precipitation. Moreover, the applications of struvite as a slow release fertilizer and some economic considerations are reported. The analysis of the numberless scientific papers examined clearly showed that struvite precipitation is a well-defined technology applicable under different modalities for the treatment of various types of wastewater. Indeed, the process proved its effectiveness both in the treatment of urban wastewater and high concentrated aqueous waste such as landfill leachate, digestates, etc. The struvite formation is mainly affected by the temperature, $\mathrm{pH}$, the type of reagents and their dosages, and the presence of competitive ions. As the struvite solubility increases with the temperature, values below $25^{\circ} \mathrm{C}$ were, generally, considered as preferable. Regarding the other parameters, quite a large variability of values considered as optimal to reach the best performance can be found in the literature reports. In particular, $\mathrm{pH}$ values in the range 7.6-10.5 were reported as suitable to promote MAP formation. Regarding the N:Mg:P molar ratio, the stoichiometric value (1:1:1) must be guaranteed to allow the struvite crystals nucleation. However, overdoses of magnesium as well as of phosphorus, if the treatment aims at $\mathrm{N}$ removal, are necessary to ensure satisfactory performance. Depending on the type of reagents used, overdoses of magnesium up to 4 , with respect to the theoretical dosage, were reported in the literature. Instead, dosages of phosphorus up to 1.3 were applied. Calcium was identified as the most competitive ion and Ca:Mg ratios lower than 0.2 were suggested to prevent the slowdown of struvite nucleation process. The parameters variability is in part attributable to the different characteristics of treated wastewater which, obviously, influence the struvite formation. Moreover, the difference in the system configurations and in the applied process modalities can also justify the variability of reported values. In general, very high performances were obtained using pure reagents. However, the consumption 
of chemicals represents a main cost item. Therefore, currently, there is great attention on the use of low-cost reagents to reduce the overall process expense. Many studies proved the possibility of exploiting several unconventional magnesium reagents and alkaline compounds to promote the struvite formation. Recently, some by-products exploitable as phosphorus reactants have been identified and effectively applied. This represents a main aspect because it makes more sustainable the struvite precipitation in the removal of ammonium nitrogen. The reuse of struvite decomposition residues, as possible reactants for the treatment of raw wastewater, has been also explored. This approach can reduce the overall process cost, but it does not allow to exploit the produced struvite in agronomic practices. The research activity is currently focused also on the optimization of reactors configurations for struvite formation and precipitation. The STR and FBR have largely proved their effectiveness and are the most applied reactors. Nevertheless, many studies are constantly in progress to further optimize these types of units. Other types of reactors, such as BES, ion exchange reactors, membrane reactors, have been investigated. However, their applicability in field conditions still appears far away. Various papers demonstrated the great value of struvite produced from the treatment of waste and wastewater as a fertilizer for the growth of many types of plants and vegetables. In effect, the struvite produced in some industrial processes is currently used as a commercial fertilizer. Therefore, it can be concluded that the struvite precipitation technology is a profitable approach for the removal and the recovery of nutrients from wastewater streams. However, further research needs to be conducted to identify other types of low-cost unconventional phosphorus sources, which could reduce process costs in wastewater treatment with high ammonium concentrations. Furthermore, the processes based on the reuse of struvite decomposition residues must be tested on a larger scale to verify their actual applicability. Finally, in the aim to exploit the struvite precipitate as slow release fertilizer, technology improvements are required to produce larger crystals that could be more easily recovered and reused.

Author Contributions: Conceptualization: A.S. and R.M.; writing and editing: A.S., C.L., and G.M.C.; data collection: C.L. and G.M.C.; review: A.S. and R.M. All authors have read and agreed to the published version of the manuscript.

Funding: This research received no external funding.

Conflicts of Interest: The authors declare no conflict of interest.

\section{References}

1. Di Iaconi, C.; Pagano, M.; Ramadori, R.; Lopez, A. Nitrogen recovery from a stabilized municipal landfill leachate. Bioresur. Technol. 2010, 101, 1732-1736. [CrossRef] [PubMed]

2. Kabdaşli, I.; Parsons, S.A.; Tünay, O. Effect of major ions on induction time of struvite precipitation. Croatica Chemica Acta 2006, 79, 243-251.

3. Kabdaşl1, I.; Tünay, O. Nutrient recovery by struvite precipitation, ion exchange and adsorption from source-separated human urine-A review. Environ. Technol. Rev. 2018, 7, 106-138. [CrossRef]

4. Siciliano, A.; Stillitano, M.A.; Limonti, C.; Marchio, F. Ammonium Removal from Landfill Leachate by Means of Multiple Recycling of Struvite Residues Obtained through Acid Decomposition. Appl. Sci. 2016, 6, 375. [CrossRef]

5. Siciliano, A.; De Rosa, S. Experimental formulation of a kinetic model describing the nitrification process in biological aerated filters filled with plastic elements. Environ. Technol. 2015, 36, 293-301. [CrossRef]

6. Zhang, W.; Dixon, M.B.; Saint, C.; Teng, K.S.; Furumai, H. Electrochemical biosensing of algal toxins in water: The current-state-of-the-art. ACS Sens. 2018, 3, 1233-1245. [CrossRef]

7. Siciliano, A.; Curcio, G.M.; Limonti, C. Experimental analysis and modeling of nitrate removal through zero-valent magnesium particles. Water 2019, 11, 1276. [CrossRef]

8. Siciliano, A.; Limonti, C.; Mehariya, S.; Molino, A.; Calabrò, V. Biofuel Production and Phosphorus Recovery through an Integrated Treatment of Agro-Industrial Waste. Sustainability 2019, 11, 52. [CrossRef]

9. Huang, H.; Zhang, D.; Wang, W.; Li, B.; Zhao, N.; Li, J.; Dai, J. Alleviating Na ${ }^{+}$effect on phosphate and potassium recovery from synthetic urine by K-struvite crystallization using different magnesium sources. Sci. Total Environ. 2019, 655, 211-219. [CrossRef] 
10. Huygens, D.; Saveyn, H.G.M.; Tonini, D.; Eder, P.; Delgado Sancho, L. Technical Proposals for Selected New Fertilising Materials under the Fertilising Products Regulation (Regulation (EU) 2019/1009)_Process and Quality Criteria, and Assessment of Environmental and Market Impacts for Precipitated Phosphate Salts E Derivates, Thermal Oxidation Materials \& Derivates and Pyrolysis E Gasification Materials, EUR 29841 EN; Publications Office of the European Union: Luxembourg, 2019; ISBN 978-92-76-09888-1.

11. Siciliano, A.; Curcio, G.M.; Limonti, C. Chemical denitrification with $\mathrm{Mg}^{0}$ particles in column systems. Sustainability 2020, 12, 2984. [CrossRef]

12. Le Corre, K.S.; Valsami-Jones, E.; Hobbs, P.; Parsons, A. Phosphorus recovery from wastewater by struvite crystallization: A review. Crit. Rev. Environ. Sci. Technol. 2009, 39, 433-477. [CrossRef]

13. Siciliano, A.; Stillitano, M.A.; De Rosa, S. Increase of the anaerobic biodegradability of olive mill wastewaters through a pre-treatment with hydrogen peroxide in alkaline conditions. Desal. Water. Treat. 2014, 55, 1735-1746. [CrossRef]

14. Siciliano, A.; Stillitano, M.A.; Limonti, C. Energetic valorization of wet olive mill wastes through a suitable integrated treatment: $\mathrm{H}_{2} \mathrm{O}_{2}$ with lime and anaerobic digestion. Sustainability 2016, 8, 1150. [CrossRef]

15. Zhang, M.; Lawlor, P.G.; Hu, Z.; Zhan, X. Nutrient removal from separated pig manure digestate liquid using hybrid biofilters. Environ. Technol. 2013, 34, 645-651. [CrossRef]

16. Siciliano, A.; De Rosa, S. An experimental model of COD abatement in MBBR based on biofilm growth dynamic and on substrates' removal kinetics. Environ. Technol. 2016, 37, 2058-2071. [CrossRef]

17. He, S.; Zhang, Y.; Yang, M.; Du, W.; Harada, H. Repeated use of MAP decomposition residues for the removal of high ammonium concentration from landfill leachate. Chemosphere 2007, 66, 2233-2238. [CrossRef]

18. Tchobanoglous, G.; Burton, F.L.; Stensel, H.D. Wastewater Engineering: Treatment and Reuse, 4th ed.; Metcalf \& Eddy Inc. McGraw-Hill: New York, NY, USA, 2003.

19. Ghosh, S.; Lobanov, S.; Lo, V.K. An overview of technologies to recover phosphorus as struvite from wastewater: Advantages and shortcomings. Environ. Sci. Pollut. R. 2019, 26, 19063-19077. [CrossRef]

20. Desmidt, E.; Ghyselbrecht, K.; Zang, Y.; Pinoy, L.; van der Bruggen, B.; Verstraete, W.; Rabaey, K.; Meesshaert, B. Global Phosphorus Scarcity and Full-Scale P-recovery techniques: A review. Crit. Rev. Environ. Sci. Technol. 2015, 45, 336-384. [CrossRef]

21. Korchef, A.; Saidou, H.; Amor, M.B. Phosphate recovery through struvite precipitation by $\mathrm{CO}_{2}$ removal: Effect of magnesium, phosphate and ammonium concentrations. J. Hazard Mater 2011, 186, 602-613. [CrossRef]

22. Saidou, H.; Moussa, B.; Ben, A.M. Influence of airflow rate and substrate nature on heterogeneous struvite precipitation. Environ. Technol. 2009, 30, 75-83. [CrossRef]

23. Fattah, K.P.; Sabrina, N.; Mavinic, D.S.; Koch, F.A. Reducing operating costs for struvite formation with a carbon dioxide stripper. Water Sci. Technol. 2008, 58, 957-962. [CrossRef] [PubMed]

24. Fattah, K.P.; Mavinic, D.S.; Koch, F.A.; Jacob, C. Determining the feasibility of phosphorus recovery as struvite from filter press centrate in a secondary wastewater treatment plant. J. Environ. Sci. Health Part A 2008, 43, 756-764. [CrossRef] [PubMed]

25. Shih, Y.J.; Abarca, R.R.M.; de Luna, M.D.G.; Huang, Y.H.; Lu, M.C. Recovery of phosphorus from synthetic wastewaters by struvite crystallization in a fluidized-bed reactor: Effects of $\mathrm{pH}$, phosphate concentration and coexisting ions. Chemosphere 2017, 173, 466-473. [CrossRef] [PubMed]

26. Suzuki, K.; Tanaka, Y.; Kuroda, K.; Hanajima, D.; Fukumoto, Y.; Yasuda, T.; Waki, M. Removal and recovery of phosphorous from swine wastewater by demonstration crystallization reactor and struvite accumulation device. Bioresour. Technol. 2007, 98, 1573-1578. [CrossRef] [PubMed]

27. Rahaman, M.S.; Mavinic, D.S.; Meikleham, A.; Ellis, N. Modelling phosphorus removal and recovery from anaerobic digester supernatant through struvite crystallization in a fluidized bed reactor. Water Res. 2014, 51, 1-10. [CrossRef]

28. Pastor, L.; Mangin, D.; Barat, R.; Seco, A. A pilot- scale study of struvite precipitation in a stirred tank reactor: Conditions influencing the process. Bioresur. Technol. 2008, 99, 6285-6291. [CrossRef]

29. Pastor, L.; Mangin, D.; Ferrer, J.; Seco, A. Struvite formation from the supernatants of an anaerobic digestion pilot plant. Biores. Technol. 2010, 101, 118-125. [CrossRef]

30. Iqbal, M.; Bhuiyan, H.; Mavinic, D.S. Assessing struvite precipitation in a pilot-scale fluidized bed crystallizer. Environ. Technol. 2008, 29, 1157-1167. [CrossRef]

31. Latifian, M.; Liu, J.; Mattiasson, B. Struvite-based fertilizer and its physical and chemical properties. Environ. Technol. 2012, 33, 2691-2697. [CrossRef] 
32. Uludag-Demirer, S.; Demirer, G.N.; Chen, S. Ammonia removal from anaerobically digested dairy manure by struvite precipitation. Process. Biochem. 2005, 40, 3667-3674. [CrossRef]

33. Uysal, A.; Yilmazel, Y.D.; Demirer, G.N. The determination of fertilizer quality of the formed struvite from effluent of a sewage sludge anaerobic digester. J. Hazard. Mater. 2010, 181, 248-254. [CrossRef] [PubMed]

34. Uysal, A.; Demir, S.; Sayilgan, E.; Eraslam, F.; Kucukyumuk, Z. Optimization of struvite fertilizer formation from baker's yeast wastewater: Growth and nutrition of maize and tomato plants. Environ. Sci. Pollut. Res. 2014, 2, 3264-3274. [CrossRef] [PubMed]

35. Wu, Y.; Zhou, S. Improving the prediction of ammonium nitrogen removal through struvite precipitation. Environ. Sci. Pollut. Res. 2012, 19, 347-360. [CrossRef]

36. Perwitasari, D.S.; Muryanto, S.; Jamari, J.; Bayuseno, A.P. Kinetics and morphology analysis of struvite precipitated from aqueous solution under the influence of heavy metals: $\mathrm{Cu}^{2+}, \mathrm{Pb}^{2+}, \mathrm{Zn}^{2+}$. J. Environ. Chem. Eng. 2018, 6, 37-43. [CrossRef]

37. Jones, A.G. Crystallization Process System; Butterworth/Heinemann: Oxford, UK, 2002; ISBN 9780750655200.

38. Bouropoulos, N.C.; Koutsoukos, P.G. Spontaneous precipitation of struvite from aqueous solutions. J. Cryst. Growth. 2000, 213, 381-388. [CrossRef]

39. Li, B.; Boiarkina, I.; Huang, H.M.; Munir, T.; Wang, G.Q.; Young, B.R. Phosphorus recovery through struvite crystallization: Challanges for future design. Sci. Total Environ. 2019, 648, 1244-1256. [CrossRef]

40. Bing, L.; Boiarkina, I.; Yu, W.; Young, B. A new thermodynamic approach for struvite product quality prediction. Environ. Sci. Pollut. Res. 2019, 26, 3954-3964. [CrossRef]

41. Siciliano, A. Assessment of fertilizer potential of the struvite produced from the treatment of methanogenic landfill leachate using low-cost reagents. Environ. Sci. Pollut. Res. 2016, 23, 5949-5959. [CrossRef]

42. Ohlinger, K.N.; Young, T.M.; Schroeder, E.D. Predicting struvite formation in digestion. Water Res. 1998, 32, 3607-3614. [CrossRef]

43. Buchanan, J.R.; Mote, C.R.; Robinson, R.B. Struvite control by chemical treatment. Trans. Am. Soc. Agric. Eng. 1994, 37, 1301-1308. [CrossRef]

44. Siciliano, A.; De Rosa, S. Recovery of ammonia in digestates of calf manure through a struvite precipitation process using unconventional reagents. Environ. Technol. 2014, 35, 841-850. [CrossRef] [PubMed]

45. Tünay, O.; Kabdaşli, I.; Orhon, D.; Kolçak, S. Ammonia removal by magnesium ammonium phosphate precipitation in industrial wastewaters. Water Sci. Technol. 1997, 36, 225-228. [CrossRef]

46. Hao, X.; Wang, C.; Van Loosdrecht, M.C.M.; Hu, Y. Looking beyond struvite for Precovery. Environ. Sci. Technol. 2013, 47, 4965-4966. [CrossRef] [PubMed]

47. Huang, H.M.; Zhang, D.D.; Li, J.; Guo, G.J.; Tang, S.F. Phosphate recovery from swine wastewater using plant ash in chemical crystallization. J. Clean. Prod. 2017, 168, 338-345. [CrossRef]

48. Tomei, M.C.; Stazi, V.; Daneshgar, S.; Capodaglio, A.G. Holistic approach to phosphorus recovery from urban 3 wastewater: Enhanced biological removal combined with precipitation. Sustainability 2020, 12, 575. [CrossRef]

49. Doyle, J.D.; Parsons, S.A. Struvite formation, control and recovery. Water Res. 2002, 36, 3925-3940. [CrossRef]

50. Siciliano, A.; Ruggiero, C.; De Rosa, S. A new integrated treatment for the reduction of organic and nitrogen loads in methanogenic landfill leachates. Process. Saf. Environ. Prot. 2013, 91, 311-320. [CrossRef]

51. Li, X.Z.; Zhao, Q.L. Recovery of ammonium-nitrogen from landfill leachate as a multi-nutrient fertilizer. Ecol. Eng. 2003, 20, 171-181. [CrossRef]

52. Kim, D.; Ryu, H.D.; Kim, M.S.; Kim, J.; Lee, S.I. Enhancing struvite precipitation potential for ammonia nitrogen removal in municipal landfill leachate. J. Hazard. Mater. 2007, 146, 81-85. [CrossRef]

53. Kim, D.; Min, K.J.; Lee, K.; Yu, M.S.; Park, K.Y. Effect of pH, molar ratios and pre-treatment on phosphorus recovery through struvite crystallization from effluent of anaerobically degisted swine wastewater. Environ. Eng. Res. 2017, 22, 12-18. [CrossRef]

54. Quintana, M.; Colmenarejo, M.F.; Barrera, J.; García, G.; García, E.; Bustos, A. Use of bioproduct of Magnesium oxide production to precipitate phosphorus and nitrogen as struvite from wastewater treatment liquors. J. Agric. Food Chem. 2004, 52, 294-299. [CrossRef] [PubMed]

55. Xavier, L.D.; Cammarota, M.C.; Yokoyama, L.; Volschan, I.J. Study of the recovery of phosphorus from struvite precipitation in supernatant line from anaerobic digesters of sludge. Water Sci. Technol. 2014, 14, 751-757. [CrossRef] 
56. Aguado, D.; Barat, R.; Bouzas, A.; Seco, A.; Ferrer, J. P-recovery in a pilot-scale struvite crystallisation reactor for source separated urine system using seawater and magnesium chloride as magnesium sources. Sci. Total Environ. 2019, 672, 88-96. [CrossRef] [PubMed]

57. Stratful, I.; Scrimshaw, M.D.; Lester, J.N. Removal of struvite to prevent problems associated with its accumulation in wastewater treatment works. Water Environ. Res. 2004, 76, 437-443. [CrossRef] [PubMed]

58. Taddeo, R.; Lepistö, R. Struvite precipitation in raw and co-digested swine slurries for nutrients recovery in batch reactors. Water Sci. Technol. 2015, 71, 892-897. [CrossRef]

59. Brown, K.; Harrison, J.; Bowers, K. Struvite precipitation from anaerobically digested diary manure. Water Air Soil Pollut. 2018, 229, 217. [CrossRef]

60. Zhang, T.; Fang, C.; Li, P.; Jiang, R. Application of struvite process for nutrient recovery fom anaerobic digesters of livestock wastewater. Environ. Prot. Eng. 2014, 40, 29-42. [CrossRef]

61. Ramaswami, S.; Behrendt, J.; Wang, G.; Eggers, S.; Otterpohl, R. Combining magnesium ammonium phosphate precipitation with membrane processes for ammonia removal from methanogenic leachate. Water Environ. J. 2016, 30, 218-226. [CrossRef]

62. Xu, S.; Luo, L.; He, H.; Liu, H.; Cui, L. Nitrogen and Phosphate Recovery from Source-Separated Urine by Dosing with Magnesite and Zeolite. Pol. J. Environ. Stud. 2015, 24, 2269-2275. [CrossRef]

63. El-Diwani, G.; El Rafie, S.; El Ibiari, N.N.; El-Aila, H.I. Recovery of ammonia nitrogen from industrial wastewater treatment as struvite slow releasing fertilizer. Desalination 2006, 214, 200-2014. [CrossRef]

64. Huang, H.; Mavinic, D.S.; Lo, K.V.; Koch, F.A. Production and Basic Morphology of Struvite Crystals from a Pilot-Scale Crystallization Process. Environ. Technol. 2006, 27, 233-245. [CrossRef] [PubMed]

65. Adnan, A.; Koch, F.A.; Mavinic, D.S. Pilot-scale study of phosphorus recovery through struvite crystallization-II. Applying in-reactor supersatuartion ratio as a process control parameter. J. Environ. Eng. Sci. 2003, 2, 473-483. [CrossRef]

66. Liu, X.; Hu, Z.; Mu, J.; Zang, H.; Liu, L. Phosphorus recovery from urine with different magnesium resourse in an air-agitated reactor. Envirn. Technol. 2014, 35, 2781-2787. [CrossRef] [PubMed]

67. Ueno, Y.; Fujii, M. Three years of operating and selling recovered struvite from full-scale plant. Environ. Technol. 2001, 22, 1373-1381. [CrossRef]

68. Bhuiyan, M.I.H.; Mavinic, D.S.; Koch, F.A. Phosphorus recovery from wastewater through struvite formation in fluidized bed reactors: A sustainable approach. Water Sci. Technol. 2008, 57, 175-181. [CrossRef]

69. Battistoni, P.; Boccadoro, R.; Fatone, F.; Pavan, P. Auto-Nucleation and Crystal Growth of Struvite in a Demonstrative Fluidized Bed Reactor (FBR). Environ. Technol. 2005, 26, 975-982. [CrossRef]

70. Guadie, A.; Xia, S.; Jiang, W.; Zhou, L.; Zhang, Z.; Hermanowicz, S.W.; Xu, X.; Shen, S. Enhanced struvite recovery from wastewater using a novel cone-inserted fluized bed reactor. J. Environ. Sci. 2014, 26, 765-774. [CrossRef]

71. Rahaman, M.S.; Ellis, N.; Mavinic, D.S. Effects of various process parameters on struvite precipitation kinetics and subsequent determination of rate constants. Water Sci. Technol. 2008, 57, 647-654. [CrossRef]

72. Jordaan, E.M.; Rezania, B.; Çiçek, N. Investigation of chemical-free nutrient removal and recovery from $\mathrm{CO}_{2}$-rich wastewater. Water Sci. Technol. 2013, 67, 2195-2201. [CrossRef]

73. Shimamura, K.; Tanaka, T.; Miura, Y.; Ishikawa, H. Development of a high-efficiency phosphorus recovery method using a fluidized-bed crystallized phosphorus removal system. Water Sci. Technol. 2003, 48, 163-170. [CrossRef]

74. Bowers, K.E.; Westerman, P.W. Performance of cone-shaped fluidized bed struvite crystallizer in removing phosphorus from wastewater. Trans. ASAE 2005, 48, 1227-1234. [CrossRef]

75. Shin, H.S.; Lee, S.M. Removal of nutrients in wastewater by using magnesium salts. Environ. Technol. 1997, 19, 283-290. [CrossRef]

76. Ryu, H.D.; Choo, Y.D.; Kang, M.K.; Lee, S.I. Integrated application of struvite precipitation and biological treatment in treating autothermal thermophilic aerobic digestion supernatant liquid. Environ. Eng. Sci. 2014, 31, 167-175. [CrossRef]

77. Tao, W.; Fattah, K.P.; Huchzermeier, M.P. Struvite recovery from anaerobically digested dairy manure: A review of application potenzial and hindrances. J. Envirin. Manag. 2016, 169, 46-57. [CrossRef]

78. Cao, X.; Harris, W. Carbonate and magnesium interactive effect on calcium phosphate precipitation. Environ. Sci. Technol. 2008, 42, 436-442. [CrossRef] [PubMed] 
79. Babić-Ivančić, V.; Kontrec, J.; Kralj, D.; Brečević, L. Precipitation diagrams of struvite and dissolution kinetics of different struvite morphologies. Croatica Chemica Acta 2002, 75, 89-106.

80. Quintana, M.; Sánchez, E.; Colmenarejo, M.F.; Barrera, J.; García, G.; Borja, R. Kinetics of phosphorus removal and struvite formation by the utilization of by-product of magnesium oxide production. Chem. Eng. J. 2005, 111, 45-52. [CrossRef]

81. Nelson, N.O.; Mikkelsen, R.L.; Hesterberg, D.L. Struvite precipitation in anaerobic swine lagoon liquid: Effect of $\mathrm{pH}$ and Mg:P ratio and determination of rate constant. Bioresour. Technol. 2003, 89, 229-236. [CrossRef]

82. Martí, N.; Pastor, L.; Bouzas, A.; Ferrer, J.; Seco, A. Phosphorus recovery by struvite crystallization in WWTPs: Influence of the sludge treatment line operation. Water Res. 2010, 44, 2371-2379. [CrossRef]

83. Jaffer, Y.; Clark, T.A.; Pearce, P.; Parson, S.A. Potential phosphorus recovery by struvite formation. Water Res. 2002, 36, 1834-1842. [CrossRef]

84. Crutchik, D.; Garrido, J.M. Kinetics of the reversible reaction of struvite crystallization. Chemosphere 2016, 154, 567-572. [CrossRef] [PubMed]

85. Capdevielle, A.; Korov, E.B.; Line, F.; Daumer, M.L. Kinetics of struvite precipitation in synthetic biologically treated swine wastewaters. Environ. Technol. 2014, 35, 1250-1262. [CrossRef] [PubMed]

86. Moussa, S.B.; Tlili, M.M.; Batis, N.; Amor, M.B. Influence of temperature on Struvite precipitation by $\mathrm{CO}_{2}$-degassing method. Cryst. Res. Technol. 2011, 46, 255-260. [CrossRef]

87. Boistelle, R.; Abbona, F.; Lundager Madsen, H.E. On the transformation of struvite into newberyite in aqueous systems. Phys. Chem. Miner. 1983, 9, 216-222. [CrossRef]

88. Aage, H.K.; Andersen, B.L.; Blom, A.; Jensen, I. The solubility of struvite. J. Radio Anal. Nucl. Chem. 1997, 223, 213-215. [CrossRef]

89. Loewenthal, R.E.; Kornmuller, U.R.C.; Van Heerden, E.P. Modelling struvite precipitation in anaerobic treatment systems. Water Sci. Technol. 1994, 30, 107-116. [CrossRef]

90. Gunay, A.; Karadag, D.; Tosun, I.; Ozturk, M. Use of magnesite as a magnesium source for ammonium removal from leachate. J. Hazard. Mater. 2008, 156, 619-623. [CrossRef]

91. Koutsoukos, P.G.; Kofina, A.N.; Klepetsanis, P.G. Exploration of Alternatives for Phosphorus Recovery from Wastewater by Crystallization; Wasic Workshop: Istanbul, Turkey, 2003.

92. Le Corre, K.S.; Valsami-Jones, E.; Hobbs, P.; Parsons, S. Impact of calcium on struvite crystal size, shape and purity. J. Crystal. Growth 2005, 283, 514-522. [CrossRef]

93. Kofina, A.N.; Koutsoukos, P. Spontaneous precipitation of struvite from synthetic wastewater. Cryst. Growth Des. 2005, 5, 489-496. [CrossRef]

94. Bhuiyan, M.I.H.; Mivinic, D.S.; Beckie, R.D. A solubility and thermodynamic study of struvite. Environ. Technol. 2007, 28, 1015-1026. [CrossRef]

95. Hanhoun, M.; Montastruct, L.; Azzaro-Pantel, C.; Biscans, B.; Fréche, M.; Pibouleau, L. Temperature impact assessment on struvite solubility product: A thermodynamic modeling approach. Chem. Eng. J. 2011, 167, 50-58. [CrossRef]

96. Harris, W.G.; Wilkie, A.C.; Cao, X.; Sirengo, R. Bench-scale recovery of phosphorus from flushed dairy manure wastewater. Bioresour. Technol. 2008, 99, 3036-3043. [CrossRef] [PubMed]

97. Zhang, T.; Bowers, K.E.; Harrison, J.H.; Chen, S. Releasing phosphorus from calcium for struvite fertilizer production from anaerobically digested dairy manure. Water Environ. Res. 2010, 82, 34-42. [CrossRef]

98. Huchzermeier, M.; Tao, W. Overcoming challenges to struvite recovery from anaerobically digested dairy manure. Water Environ. Res. 2012, 84, 34-41. [CrossRef]

99. Fattah, K.P.; Zhang, Y.; Mavinic, D.S.; Koch, F.A. Use of carbon dioxide stripping for struvite crystallization to save caustic dosage: Performance at pilot-scale operation. Can. J. Civ. Eng. 2010, 37, 1271-1275. [CrossRef]

100. Zhao, Q.-B.; Ma, J.; Zeb, I.; Yu, L.; Chen, S.; Zheng, Y.-M.; Frear, C. Ammonia recovery from anaerobic digester effluent through direct aeration. Chem. Eng. J. 2015, 279, 31-37. [CrossRef]

101. Kabdaşli, I.; Tünay, O.; Özcan, P. Application of struvite precipitation coupled with biological treatment to slaughterhouse wastewaters. Environ. Technol. 2009, 30, 1095-1101. [CrossRef]

102. Chimenos, J.M.; Fernández, A.I.; Villalba, G.; Segarra, M.; Urruticoechea, A.; Artazab, B.; Espiella, F. Removal of ammonium and phosphates from wastewater resulting from the process of cochineal extraction using MgO-containing by-product. Water Res. 2003, 37, 1601-1607. [CrossRef]

103. Lee, S.I.; Weon, S.Y.; Lee, C.W.; Koopman, B. Removal of nitrogen and phosphate from wastewater by addition of bittern. Chemosphere 2003, 51, 265-271. [CrossRef] 
104. Huang, H.; Xu, C.; Zhang, W. Removal of nutrients from piggery wastewater using struvite precipitation and pyrogenation technology. Bioresour. Technol. 2011, 102, 2523-2528. [CrossRef]

105. Huang, H.; Jiang, Y.; Ding, L. Recovery and removal of ammonia-nitrogen and phosphate from swine wastewater by internal recycling of struvite chlorination product. Bioresour. Technol. 2014, 172, 253-259. [CrossRef] [PubMed]

106. Huang, H.; Liu, J.; Jiang, Y. Crystallization and precipitation of phosphate from swine wastewater by magnesium metal corrosion. Sci. Rep. 2015, 5, 16601. [CrossRef] [PubMed]

107. Wang, F.; Wei, J.; Zou, X.; Fu, R.; Li, J.; Wu, D.; Lv, H.; Zhu, G.; Wu, X.; Chem, H. Enhanced electrochemical phosphate recovery from livestock wastewater by adjusting $\mathrm{pH}$ with plant ash. J. Environ. Manag. 2019, 250, 109473. [CrossRef] [PubMed]

108. Le Corre, K.S.; Valsami-Jones, E.; Hobbs, P.; Parsons, S.A. Impact of Reactor Operation on Success of Struvite Precipitation from Synthetic Liquors. Environ. Technol. 2007, 28, 1245-1256. [CrossRef]

109. Kataki, S.; West, H.; Clarke, M.; Baruah, D.C. Phosphorus recovery as struvite: Recent concerns for use of seed, alternative Mg source, nitrogen conservation and fertilizer potential. Resur. Conserv. Recy. 2016, 107, 142-156. [CrossRef]

110. Yetilmezsoy, K.; Zengin, Z.S. Recovery of ammonium nitrogen from the effluent of UASB treating poultry manure wastewater by MAP precipitation as a slow release fertilizer. J. Hazard. Mater. 2009, 166, 260-269. [CrossRef]

111. Munch, E.V.; Barr, K. Controlled struvite crystallization for removing phosphorus from anaerobic digester sidestreams. Water Res. 2001, 35, 151-159. [CrossRef]

112. Kruk, D.J.; Elektorowicz, M.; Oleszkiewicz, J.A. Struvite precipitation and phosphorus removal using magnesium sacrificial anode. Chemosphere 2014, 101, 28-33. [CrossRef]

113. Hug, A.; Udert, K.M. Struvite precipitation from urine with electrochemical magnesium dosage. Water Res. 2013, 47, 289-299. [CrossRef]

114. Song, G.; Atrens, A.; John, D.; Wu, X. The anodic dissolution of magnesium in chloride and sulphate solutions. Corros. Sci. 1997, 39, 1981-2004. [CrossRef]

115. Krähenbühl, M.; Etter, B.; Udert, K.M. Pretreated magnesite as a source of low cost magnesium for producing struvite from urine in Nepal. Sci. Total Environ. 2016, 542, 1155-1161. [CrossRef] [PubMed]

116. Etter, B.; Tilley, E.; Khadka, R.; Udert, K.M. Low-cost struvite production using source-separated urine in nepal. Water Res. 2011, 45, 825-862. [CrossRef] [PubMed]

117. Rubio-Rincón, F.J.; Lopez-Vasquez, C.M.; Ronteltap, M.; Brdjanovic, D. Seawater for phosphorus recovery from urine. Desalination 2014, 348, 49-56. [CrossRef]

118. Sakthivel, S.R.; Tilley, E.; Udert, K.M. Wood ashas a magnesium source for phosphorus recovery from source-seprated urine. Sci. Total Environ. 2012, 419, 68-75. [CrossRef] [PubMed]

119. Liu, B.; Giannis, A.; Zhang, J.; Chang, V.; Wang, J.Y. Characterization of induced struvite formation from source-separated urine using seawater and brine as magnesium sources. Chemosphere 2013, 93, 2738-2747. [CrossRef]

120. Myllymäki, P.; Pesonen, J.; Nurmesniemi, E.T.; Romar, H.; Tynjälä, P.; Hu, T.; Lassi, U. The Use of Industrial Waste Materials for the Simultaneous Removal of Ammonium Nitrogen and Phosphate from the Anaerobic Digestion Reject Water. Waste Biomass Valor. 2020, 11, 4013-4024. [CrossRef]

121. Huang, H.; Xiao, D.; Zhang, Q.; Ding, L. Removal of ammonia from landfill leachate by struvite precipitation with the use of low-cost phosphate and magnesium sources. J. Environ. Manag. 2014, 145, 191-198. [CrossRef]

122. Darwish, M.; Aris, A.; Puteh, M.H.; Jusoh, M.N.H.; Kadir, A.A. Waste bones ash as an alternative source of P for struvite precipitation. J. Environ. Manag. 2017, 203, 861-866. [CrossRef]

123. Ylivainio, K.; Uusitaloand, R.; Turtola, E. Meat bone meal and fox manure as P sources for ryegrass (loliummultiflorum) grown on a limited soil. Nutr. Cycl. Agroecosyst 2008, 81, 267-278. [CrossRef]

124. Coutand, M.; Cyr, M.; Deydier, E.; Guilet, R.; Clastres, P. Characteristics of industrial and laboratory meat and bone meal ashes and their potential applications. J. Hazard. Mater. 2008, 150, 522-532. [CrossRef]

125. Deydier, E.; Guilet, R.; Sarda, S.; Sharrock, P. Physical and chemical characterisation of crude meat and bone meal combustion residue: “waste or raw material?". J. Hazard. Mater. 2005, 121, 141-148. [CrossRef] [PubMed] 
126. Moerman, W.; Carballa, M.; Vandekerckhove, A.; Derycke, D.; Verstraete, W. Phosphate removal in agro-industry: Pilot- and full-scale operational considerations of struvite crystallization. Water Res. 2009, 43, 1887-1892. [CrossRef] [PubMed]

127. Fattah, K.; Mavinic, D.; Koch, F. Influence of process parameters on the characteristics of struvite pellets. J. Environ. Eng. 2015, 138, 1200-1209. [CrossRef]

128. Huang, H.; Xiao, D.; Liu, J.; Hou, L.; Ding, L. Recovery and removal of nutrients from swine wastewater by using a novel integrated reactor for struvite decomposition and recycling. Sci. Rep. 2015, 5, 10183. [CrossRef] [PubMed]

129. Zhang, S.; Yao, C.; Feng, X.; Yang, M. Repeated use of $\mathrm{MgNH}_{4} \mathrm{PO}_{4} \cdot 6 \mathrm{H}_{2} \mathrm{O}$ residues for ammonium removal by acid dipping. Desalination 2004, 170, 27-32. [CrossRef]

130. Liu, Y.H.; Rahman, M.M.; Kwag, J.H.; Kim, J.H.; Ra, C.S. Eco-friendly production of maize using struvite recovered from swine wastewater as a sustainable fertilizer source. Asian-Aust. J. Anim. Sci. 2011, 24, 1699-1705. [CrossRef]

131. Zhang, T.; Ding, L.; Ren, H.; Xiong, X. Ammonium nitrogen removal from coking wastewater by chemical precipitation recycle technology. Water Res. 2009, 43, 5209-5215. [CrossRef]

132. Zhang, T.; Wu, X.; Li, H.; Tsang, D.C.W.; Li, G.; Ren, H. Struvite pyrolysate cycling technology assisted by thermal hydrolysis pretreatment to recover ammonium nitrogen from composting leachate. J. Clean. Prod. 2020, 242, 118442. [CrossRef]

133. Yu, R.; Geng, J.; Ren, H.; Wang, Y.; Xu, K. Struvite pyrolysate recycling combined with dry pyrolysis for ammonium removal from wastewater. Bioresour. Technol. 2013, 132, 154-159. [CrossRef]

134. Türker, M.; Celen, I. Removal of ammonia as struvite from anaerobic digester effluents and recycling of magnesium and phosphate. Bioresour. Technol. 2007, 98, 1529-1534. [CrossRef]

135. Liu, Y.H.; Kumar, S.; Kwag, J.H.; Kim, J.H.; Kim, J.D.; Ra, C.S. Recycle of electrolytically dissolved struvite as an alternative to enhance phosphate and nitrogen recovery from swine wastewater. J. Hazard. Mater. 2011, 195, 175-181. [CrossRef] [PubMed]

136. Momballiu, A.; Desmidt, E.; Ghyselbrecht, K.; Meesschaert, B. Phoshate recovery as hydroxyapatite from nitrified UASB effluent at neutral pH in a CSTR. J. Environ. Chem. Eng. 2018, 6, 4413-4422. [CrossRef]

137. Gao, Y.; Ling, B.; Chen, H.; Yin, P. An experimental study on the recovery of potassium (K) and phosphorous (P) from synthetic urine by crystallization of magnesium potassium phosphate. Chem. Eng. J. 2018, 337, 19-29. [CrossRef]

138. Ohlinger, K.N.; Young, T.M.; Schroeder, E.D. Kinetics effects on preferential struvite accumulation in wastewater. J. Environ. Eng. 1999, 125, 730-737. [CrossRef]

139. Mangin, D.; Klein, J.P. Fluid dynamic concepts for a phosphate precipitation reactor design. In Phosphorus in Environmental Technologies: Principles and Applications; IWA Publishing: London, UK, 2004; pp. 358-401.

140. Ohlinger, K.N.; Membre, P.E.; Young, T.M.; Schroeder, E.D. Post digestion struvite precipitation using a fluidized bed reactor. J. Environ. Eng. 2000, 126, 361-368. [CrossRef]

141. Suzuki, K.; Tanaka, Y.; Juroda, K.; Hanajima, D.; Fukumoto, Y. Recovery of phosphorous from swine wastewater through crystallization. Bioresur. Technol. 2005, 96, 1544-1550. [CrossRef] [PubMed]

142. Liu, Z.; Zhao, Q.; Lee, D.J.; Yang, N. Enhancing phosphorus recovery by a new internal recycle seeding MAP reactor. Bioresour. Technol. 2008, 99, 6488-6493. [CrossRef]

143. Liu, Y.H.; Kwnag, J.H.; Kim, J.H.; Ra, C.S. Recovery of nitrogen and phosphorus by struvite crystallization from swine wastewater. Desalination 2011, 277, 364-369. [CrossRef]

144. Modin, O.; Gustavsson, D.J.I. Opportunities for microbial electrochemistry in municipal wastewater treatment-An overview. Water Sci. Technol. 2014, 69, 1359-1372. [CrossRef]

145. Pant, D.; Singh, A.; Van Bogaert, G.; Irving Olsen, S.; Singh Nigam, P.; Diels, L.; Vanbroekhoven, K. Bioelectrochemical systems (BES) for sustainable energy production and product recovery from organic wastes and industrial wastewaters. RSC Adv. 2012, 2, 1248-1263. [CrossRef]

146. Cusick, R.D.; Logan, B.E. Phosphate recovery as struvite within a single chamber microbial electrolysis cell. Bioresur. Technol. 2012, 107, 110-115. [CrossRef] [PubMed]

147. Cusick, R.D.; Ullery, M.L.; Dempsey, B.A.; Logan, B.E. Electrochemical struvite precipitation from digestate with a fluidized bed cathode microbial electrolysis cell. Water Res. 2014, 54, 297-306. [CrossRef] [PubMed]

148. You, J.; Greenman, J.; Melhuish, C.; Ieropoulos, I. Electricity generation and struvite recovery from human urine using microbial fuel cells. J. Chem. Technol. Biot. 2016, 91, 647-654. [CrossRef] 
149. Kelly, T.P.; He, Z. Nutrients removal and recovery in bioelectrochemical systems: A review. Bioresour. Technol. 2014, 153, 351-360. [CrossRef] [PubMed]

150. Hirooka, K.; Ichihashi, O. Phosphorus recovery from artificial wastewater by microbial fuel cell and its effect on power generation. Bioresur. Technol. 2013, 137, 368-375. [CrossRef]

151. Chen, T.; Barton, S.C.; Binyamin, G.; Gao, Z.; Zhang, Y.; Kim, H.H.; Heller, A. A miniature biofuel cell. J. Am. Chem. Soc. 2001, 123, 8630-8631. [CrossRef]

152. Liu, H.; Cheng, S.; Logan, B.E. Production of electricity from acetate or butyrate using a single-chamber microbial fuel cell. Environ. Sci. Technol. 2005, 32, 658-662. [CrossRef]

153. Rabaey, K.; Verstraete, W. Microbial fuel cells: Novel biotechnology for energy generations. Trends Biotechnol. 2005, 23, 291-298. [CrossRef]

154. Kim, B.H.; Kim, H.J.; Hyun, M.S.; Park, D.H. Direct electrode reaction of Fe (III) reducing bacterium, Shewanellaputrefacience. J. Microbiol. Biotechnol. 1999, 9, 127-131. [CrossRef]

155. Cuong, A.P.; Jung, S.J.; Phung, N.T.; Lee, J.; Chang, I.S.; Kim, B.H.; Yi, H.; Chun, J. A novel electrochemically active and $\mathrm{Fe}$ (III)-reducing bacterium phylogenetically related to Aeromonas hydrophila, isolated from a microbial fuel cell. FEMS Microbiol. Lett. 2003, 223, 129-134. [CrossRef]

156. Fischer, F.; Bastian, C.; Happe, M.; Mabillard, E.; Schmidt, N. Microbial fuel cell enables phosphate recovery from digested sewage sludge as struvite. Bioresur. Technol. 2011, 102, 5824-5830. [CrossRef] [PubMed]

157. Ichihashi, O.; Hirooka, K. Removal and recovery of phosphorus as struvite from swine wastewater using microbial fuel cell. Bioresour. Technol. 2012, 114, 303-307. [CrossRef] [PubMed]

158. Fornero, J.J.; Rosenbaum, M.; Cotta, M.A.; Angenent, L.T. Carbon dioxide addition to microbial fuel cell cathodes maintains sustainable catholyte $\mathrm{pH}$ and improves anolyte $\mathrm{pH}$, alkalinity, and conductivity. Environ. Sci. Technol. 2010, 44, 2728-2734. [CrossRef] [PubMed]

159. Santoro, C.; Ieropoulos, I.; Greenman, J.; Cristiani, P.; Vadas, T.; Mackay, A.; Li, B. Power generation and contaminant removal in single chamber microbial fuel cells (SCMFCs) treating human urine. Int. J. Hydrogen Energy 2013, 38, 11543-11551. [CrossRef]

160. Tao, Q.; Zhou, S.; Luo, J.; Yuan, J. Nutrient removal and elctricity production from wastewater using microbial fuel cell technique. Desalinization 2015, 365, 92-98. [CrossRef]

161. Almatouq, A.; Babatunde, A.O. Concurrent hydrogen production and phosphorus recovery in dual chamber microbial electrolysis cell. Bioresur. Technol. 2017, 237, 193-203. [CrossRef]

162. Tang, X.; Li, H.; Du, Z.; Ng, H.Y. A phosphorus-free anolyte to enhance coulombic efficiency of microbial fuel cells. J. Power Sources 2014, 268, 14-18. [CrossRef]

163. Petruzzelli, D.; Dell'Erba, A.; Liberti, L.; Notarnicola, M.; Sengupta, A.K. A phosphate-selective sorbent for the REM NUT ${ }^{\circledR}$ process: Field experience at Massafra Wastewater Treatment Plant. React. Funct. Polym. 2003, 60, 195-2020. [CrossRef]

164. Nur, T.; Loganathan, P.; Kandasamy, J.; Vigneswaran, S. Phosphate Adsorbtion from Membrane bioreactor effluent using Dowex 21K XLT and recovery as struvite and idroxyapatite. Int. J. Environ. Res. Public Health 2016, 13, 277. [CrossRef]

165. Mijangos, F.; Kamel, M.; Lesmes, G.; Muraviev, D.N. Synthesis of struvite by ion exchange isothermal supersaturation technique. React. Funct. Polym. 2004, 60, 151-161. [CrossRef]

166. Mijangos, F.; Celaya, A.; Ortueta, M.; Muraviev, D. Analysis of ion exchange isothermal supersaturation process for struvite production. Ind. Eng. Chem. Res. 2013, 52, 10276-10283. [CrossRef]

167. Ortueta, M.; Celaya, A.; Mijangos, F.; Muraviev, D. Ion Exchange synthesis of struvite accompanied by isothermal supersaturation: Influence of polymer matrix and functional groups Type. Solvent Extr. Ion Exch. 2015, 33, 65-74. [CrossRef]

168. Gonder, Z.B.; Kaya, Y.; Vergili, I.; Barlas, H. Capacity loss in an organically fouled anion exchanger. Desalination 2006, 189, 303-307. [CrossRef]

169. van Reis, R.; Zydney, A. Bioprocess membrane technology. J. Membrane Sci. 2007, 297, 16-50. [CrossRef]

170. Sengupta, S.; Nawaz, T.; Beaudry, J. Nitrogen and phosphorus recovery from wastewater. Curr. Pollut. Rep. 2015, 1, 155-166. [CrossRef]

171. Pramanik, B.K.; Hai, F.I.; Ansari, A.J.; Roddick, F.A. Mining phosphorus from anaerobically treated dairy manure by forward osmosis membrane. J. Ind. Eng. Chem. 2019, 78, 425-432. [CrossRef]

172. Bu, F.; Du, S.; Xie, L.; Cao, R.; Zhou, Q. Swine manure treatment by anaerobic membrane bioreactor with carbon, nitrogen and phospforusrecovery. Water Sci. Technol. 2017, 76, 1939-1949. [CrossRef] [PubMed] 
173. Kumar, R.; Pal, P. Membrane-integrated hybrid system for the effective treatment of ammoniacal wastewater of coke-making plant: A volume reduction approach. Environ. Technol. 2014, 35, 2018-2027. [CrossRef]

174. Monfet, E.; Aubry, G.; Ramirez, A.A. Nutrient removal and recovery from digestate: A review of the technology. Biofuels 2018, 9, 247-262. [CrossRef]

175. Volpin, F.; Heo, H.; Johir, M.A.H.; Cho, J.; Phuntsho, S.; Shon, H.K. Techno-economic feasibility of recovering phosphorus, nitrogen and water from dilute human urine via forward osmosis. Water Res. 2019, 150, 47-55. [CrossRef]

176. Hakimi, M.H.; Jegatheesan, V.; Navaratna, D. The potential of adopting struvite precipitation as a strategy for the removal of nutrients from pre-AnMBR treated abattoir wastewater. J. Environ. Manag. 2020, 259, 109783. [CrossRef] [PubMed]

177. Zhang, J.; She, Q.; Chang, V.W.; Tang, C.Y.; Webster, R.D. Mining nutrients (N, K, P) from urban source-separated urine by forward osmosis dewatering. Environ. Sci. Technol. 2014, 48, 3386-3394. [CrossRef] [PubMed]

178. Xue, W.; Tobino, T.; Nakajima, F.; Yamamoto, K. Seawater-driven forward osmosis for enrichingnitrogen and phosphorous in treated municipal waste water: Effect of membrane properties and feed solution chemistry. Water Res. 2015, 69, 120-130. [CrossRef] [PubMed]

179. Xie, M.; Nghiem, L.D.; Price, W.E.; Elimelech, M. Toward Resource Recovery from Wastewater: Extraction of Phosphorus from Digested Sludge Using a Hybrid Forward Osmosis-Membrane Distillation Process. Environ. Sci. Technol. Lett. 2014, 1, 191. [CrossRef]

180. Benisch, M.; Baur, R.; Britton, A.; Neethling, J.B.; Oleszkiewicz, J.A. Startup of the first commercial phosphorus recycling facility in the US at Durham AWWTP. Proc. Water Environ. Fed. 2009, 2009, 102-119. [CrossRef]

181. Cornel, P.; Schaum, C. Phosphorus recovery from wastewater: Needs, technologies and costs. Water Sci. Technol. 2009, 59, 1069-1076. [CrossRef]

182. Heinzmann, B.; Engel, G. Induced magnesium ammonium phosphate precipitation to prevent incrustations and measures for phosphorus recovery. Water Pract. Technol. 2006, 1. [CrossRef]

183. Zhang, T.; Jiang, R.; Deng, Y. Phosphous recovery by struvite crystallization from livestock wastewater and reuse as fertilizer: A review. Physico-Chem. Wastewater Treat. Resour. Recover. 2017, 135-152. [CrossRef]

184. Peng, L.; Dai, H.; Wu, Y.; Peng, Y.; Lu, X. A comprensive review of phosphorus recovery from wastewater by cristallization processes. Chemosphere 2018, 197, 768-781. [CrossRef]

185. The European Parliament and the Council of the European Union. Regulation (EU) 2019/1009 of the European Parliament and the Council of 5 June 2019 Laying Down Rules on the Making Available on the Market of EU Fertilising Products and Amending Regulations (EC) No 1069/2009 and (EC) No 1107/2009 and Repealing Regulation (EC) No 2003/2003; Official Journal of the European Union: Brussels, Belgium, 2019; p. L 170/1-114.

186. Ryu, H.D.; Lim, C.S.; Kang, M.K.; Lee, S.I. Evaluation of struvite obtained from semiconductor wastewater as a fertilizer in coultivating Chinese cabbage. J. Hazard. Mate. 2012, 221-222, 248-255. [CrossRef]

187. Cao, L.; Wang, J.; Xiang, S.; Huang, Z.; Ruan, R.; Liu, Y. Nutrient removal from digested swine wastewater by combining ammonia stripping with struvite precipitation. Environ. Sci. Pollut. Res. 2019, 26, 6725-6734. [CrossRef] [PubMed]

188. Dockhorn, T. About the Economy of Phosphorus Recovery. In International Conference on Nutrient Recovery from Wastewater Streams, Vancouver, Canada; IWA Publishing: London, UK, 2009; pp. 145-158. ISBN 9781843392323.

(C) 2020 by the authors. Licensee MDPI, Basel, Switzerland. This article is an open access article distributed under the terms and conditions of the Creative Commons Attribution (CC BY) license (http://creativecommons.org/licenses/by/4.0/). 